\title{
PEÑA BATLLE Y SU CONCEPTO HISTORICO DE LA NACION DOMINICANA
}

\section{RESUMEN}

El carácter de la formación nacional ha sido un tema clásico del pensamiento sociopolítico dominicano. Desde principios de siglo se ensaya dentro de la tradición liberal democrática fundada por Hostos y continuada por Américo Lugo. Peña Batlle se forma en la atmósfera hostosiana, pero no fue menos sensible a los cambios intelectuales de la época posterior a la Gran Guerra (19141918); ambas vertientes las reflejan sus primeros escritos. A partir de los años 40 formuló una tesis alternativa del problema nacional de carácter autoritario, pretendiendo apoyarse en Lugo. En este trabajo se aborda el proceso de su evolución ideológica y se examinan los componentes de su proposición alternativa en referencia a su producción histórica.

Pese a que este artículo se ciñe a un solo aspecto de la obra de Peña Batlle, ${ }^{1}$ el tratamiento no podrá sino esbozar en forma general la discusión sobre su concepto acerca de la formación nacional dominicana. Este límite atiende no sólo al hecho de que el tema está vinculado a la comprensión de las nociones de lo

1 Manuel Arturo Peña Batlle (1902-1954), nació en Santo Domingo (República Dominicana): licenciado en derecho (1921) por la universidad de esa ciudad. Inició su carrera política dentro del movimiento nacionalista contra la ocupación norteamericana (1916-1924). Se opuso al gobierno de Trujillo (1930-1961) en los primeros años, aunque a partir de 1935 comienza su aproximación pública hacia el régimen; ya desde 1941 es de las figuras clave del mismo. Desempeñó las carteras de Interior y Policía; Economía Nacional y Relaciones Exteriores; fue consejero de la Embajada dominicana en Haití y embajador extraordinario y plenipotenciario. Historiador y ensayista, fue profesor de la Universidad de Santo Domingo, miembro de la Academia Dominicana de la Historia, del Instituto de Investigaciones Históricas de México, del Instituto de Historia de Cuba, y de honor en el Instituto de Cultura Hispánica de Madrid. Bajo su dirección en 1944 se publicó la Colección Trujillo (40 volúmenes) con motivo del centenario de la República. En 1946 apareció su Historia de la cuestión fronteriza dominico-haitiana y en 1951. La isla de La Tortuga, dos de sus obras más importantes. 
nacional esbozadas previamente en la tradición liberal del pensamiento sociopolítico dominicano, lo que de por sí amerita un estudio crítico, ${ }^{2}$ sino, y sobre todo, a que es una pieza clave de su pensamiento de historiador y político. Tal es la importancia de dicha problemática en este autor que se puede afirmar, sin temor a equivocarse, que lo más característico de su producción intelectual lo constituye el intento de otorgar a aquélla una sólida fundamentación conservadora. Su tentativa es principalmente de carácter histórico y político, aunque no deja de tener múltiples implicaciones en otros campos que no podemos desarrollar en el breve espacio de estas páginas, por lo que nos limitaremos a presentar en las líneas siguientes sólo aquellos argumentos que conciernen a su producción historiográfica.

Por tal fundamentación conservadora se entiende la empresa ideológica de dar razón de la existencia del conglomerado dominicano que: a) parte de una formación nacional «pura» ubicada en abstracto en el pasado contra la que se oponen «conspiraciones» que impiden su desarrollo. b) Reduce el campo de análisis de lo social a lo nacional. c) Adopta para ello el punto de vista de la autoridad, del poder; proponiendo el problema en términos del rescate o defensa frente al «enemigo» - el «otro»- de las «esencias verdaderas» de la nación identificadas, en el momento en que escribe, con el orden vigente.

No se nos escapa el papel que jugó Peña Batlle durante el dominio despótico trujillista (1930-1961), y en efecto, una de las motivaciones profundas que lo impulsó a acometer la empresa intelectual de superar la noción liberal precedente estuvo dada por la preocupación de ajustar en una correspondencia duradera, orgánica, la relación entre proyecto nacional y esa modalidad de la dominación social burguesa. En los hechos, hasta entonces esos dos elementos estuvieron disociados y a menudo en conflicto, pues desde antes, en el plano teórico, las aspiraciones de una sociedad burguesa habían encontrado asidero en los proyectos

2 Un planteamiento preliminar de esta problemática en Rodríguez, Genero et al.: Actualidad y perspectivas de la cuestión nacional en la Repriblica Dominicana, Santo Domingo, 1986. 
liberales que desde finales del siglo pasado se apoyaban en las concepciones democráticas de Eugenio María de Hostos (18391903). Por otra parte, en su eficacia inmediata, nada desdeñable, su labor apuntalaba el régimen de Trujillo al conferirle el sentido histórico de «rescatar» las bases económicas y «purificar» de taras y elementos sospechosos la nacionalidad dominicana; mas el alcance de la obra de este autor no parece restringirse a ello. ${ }^{3}$

\section{UNA HERENCIA INCÓMODA}

A través de sus escritos se advierte un curioso itinerario ideológico que va desde las posturas nacionalistas y antiimperialistas, radicalizadas hacia los años treinta en un discurso socializante, aunque sea de carácter burgués, ${ }^{4}$ hasta las concepciones reaccionarias que denotaban «una explícita modalidad de autoritarismo». ${ }^{5}$

Sus presupuestos iniciales remiten a la escuela hostosiana, ${ }^{6}$ la que más tarde será el blanco de sus críticas más enconadas. Entre ambos momentos puede señalarse un elemento común que fue tornándose crucial a medida que avanzaba en su teorización despótica: el prejuicio antihaitiano, cuyos antecedentes trascienden el alcance de este artículo. ${ }^{7}$ Aunque racista, a tono con la concep-

3 La semblanza que de él hiciera Joaquín Balaguer algunos años después de la caída de la dictadura bien puede tomarse como indicador de la trascendencia que para el pensamiento conservador tiene la obra de este autor: «Manuel Arturo Peña Batlle, sucesor del genio y del patriotismo de Emiliano Tejera, sigue siendo la inteligencia más sólida y la conciencia más pura de su generación a pesar de' haber sido en sus últimos años el mentor de Trujillo en el campo de las relaciones internacionales y el teorizante de la magna empresa patriótica que ha pasado a la historia con el nombre de 'nacionalización fronteriza'». Balaguer, Joaquín: Entre la sangre del 30 de mayo y la del 24 de abril. Santo Domingo, 1983, pág. 193.

4 En particular, cabe mencionar ell prólogo que escribiera en 1932 para la obra de Enrique Jiménez, Economía social americana (Santo Domingo), donde se autoproclama socialista.

5 Cassá. Roberto: Capitalismo y dictadura. Santo Domingo, 1982, pág. 774.

6 Véanse González, Raymundo: Notas sobre el pensamiento social y politico dominicano, «Estudios Sociales», Año 20, núm. 67, págs. 1-2ఓ¿, Santo Domingo, enero-marzo 1987.

$7 \mathrm{Al}$ respecto véase Cassá, Roberto: El racismo en la ideología de la clase dominante dominicana, «Ciencia», Año 3 , núm. 1, págs. 59-86, Santo Domingo, eneromarzo 1976. 
ción positivista que asumía, ${ }^{8}$ en dicha escuela operaba una suerte de compensación, gracias a los postulados democráticos que defendía, que el propio Hostos subrayó en más de un lugar para el caso dominicano. ${ }^{9}$ De manera que dentro de una concepción hostosiana ortodoxa no podía sustentarse un concepto nacional cuyo eje fuese el racismo, aun cuando lo contuviera en forma subsidiaria.

Pero el racismo no fue el elemento que determinó la inflexión en la evolución ideológica de Peña Batlle. La relativización de las concepciones liberales que heredaba, formó parte de un proceso global de frustración de las energías intelectuales y morales del nacionalismo radical, incapaz de articular un proyecto viable de organización nacional, a pesar de haber ocupado casi todo el tiempo la dirección política desde la caída del dictador Heureaux en 1899 hasta la ocupación imperialista en 1916. También para aquellos que defendieron esta última como alternativa económica, por cuanto significaría un sensible avance de los principios de la economía liberal, fue cuesta arriba sostenerse en sus posiciones. Los efectos de la Gran Guerra, finalizada en 1918, habían declarado la crisis de la economía liberal; en el país la reducción de los precios internacionales del azúcar desde 1921, fue un primer golpe. Pero la época de entreguerras iba a tener muy pronto una recesión generalizada que estalló en 1929 afectando todas las economías y generando una parálisis del comercio internacional, que sólo se recuperará tras la Segunda Guerra. Volviendo a la República Dominicana, la crisis iniciada en 1929 borraría los vestigios de progreso que pudieron haberse atribuido a la economía monopólica azucarera. Así las cosas, el panorama desde la perspectiva liberal se tornaba particularmente sombrío. Ese clima intelectual

8 El racismo en la actitud cientificista dell siglo XIX constituye un lugar común y de ninguna manera pertenece con exclusividad a la escuela hostosiana; cfr. Hobsbawm, Eric: La era del capitalismo, tomo II, Barcelona, 1977. Sin embargo, anotar el hecho de que las recusaciones de ese criterio racista en el Caribe, desde el mismo siglo XIX, estuvieron asociadas a proyectos políticos que involucraban un fuerte carácter popular, como fue el caso de la ideología revolucionaria de la guerra de independencia cubana.

9 Los escritos de Hostos en Rodríguez Demorizi, Emilio: Hostos en Santo Domingo, 2 vols., Ciudad Trujillo (vol. 1), 1939 y (vol. 2), 1942. 
no es ajeno al giro que dará la producción de nuestro autor que se dirigirá en forma determinante hacia la historia.

El impacto de la crisis económica y política, estuvo además potenciado por el influjo mundial de la revolución bolchevique cuyos ecos se hicieron sentir desde temprano en Santo Domingo. En ese orden las propuestas sociales burguesas requerían redifiniciones en las que fueron pioneros algunos intelectuales procedentes del liberalismo, como fue el caso de Enrique Jiménez, cuya obra prologara Peña Batlle. De esa forma, en una línea paralela a la crisis del liberalismo se desarrollaba una nueva pugna ideológica que resultaba del desarrollo de nuevos sectores sociales explotados a partir de la expansión de la economía capitalista y de sectores no capitalistas que crecieron subordinados a ella en el ámbito urbano, influidos por el auge comercial externo. ${ }^{10}$ Pero fuera del prólogo citado, todavía no son manifiestas estas consecuencias políticas en los primeros estudios históricos de Peña Batlle.

Si nos atenemos a sus palabras, el primer trabajo de envergadura lo realizaría en 1928 cuando acopiaba los materiales necesarios para la tarea de demarcación de la línea fronteriza entre la República de Haití y la República Dominicana. "Su publicación, dieciocho años más tarde, habla de la metamorfosis de sus concepciones, como tendremos ocasión de ver más adelante. Otro escrito temprano que sí vio la luz en este período fue publicado en España en 1931. Eleborado durante su estancia en la frontera dominicohaitiana, contiene una visión sintética del período colonial de la isla opuesta a la que sustentará con ahínco posteriormente.

El descubrimiento de América y sus vinculaciones con la

10 Un excelente estudio de esas manifestaciones ideológicas se halla en Cassá, Roberto: Movimiento obrero y lucha socialista en la República Dominicana. (Desde los origenes hasta 1960), Santo Domingo 1990.

11 Según anota en las «Palabras previas» de su Historia de la cuestión fronteriza dominico-haitiana, tomo I, Ciudad Trujillo, 1946, ell material de ese libro había sido preparado desde 1928, aunque el mismo autor señala que en esa forma el escrito no hubiera visto la luz nunca. Peña Batlle al año siguiente presidió la Comisión nombrada por el gobierno de Horacio Vázquaz con la finalidad de establecer la línea fronteriza con Haití; cfr., pág. 380 n. 
política internacional de la época, ${ }^{12}$ es un escrito breve donde Peña Batlle llega a algunas conclusiones similares a las de Hostos respecto a la política colonial ibérica. Con las providencias de establecer un Consejo para la dirección de los negocios de Indias, una lonja en Sevilla y una aduana en Cádiz, que darían origen a la Casa de Contratación, «se echaban desde entonces las bases de la funesta política comercial que estableció España en sus relaciones con las colonias de América», cuyo comercio quedó cual coto cerrado «para formar parte en cierta manera de las rentas exclusivas de la Corona». Contrapone la idoneidad del plan de colonización por el sometimiento de los territorios y los pueblos indígenas a la jurisdicción real con la expansión poblacional y económica -que implicaba, a las «férreas y absurdas disposiciones que, casi al mismo tiempo, se dictaban sobre el comercio con las Indias y que se convirtieron más tarde en el funesto sistema colonial español de los siglos XVI, XVII y XVIII». ${ }^{13}$

Frente a España colocaba las demás potencias europeas que el autor considera como interlocutores válidos de la política colonial hispánica: «Holanda e Inglaterra eran dos potencias protestantes que no se sentían ligadas a la arbitraria disposición de la Santa Sede; Francia, aunque católica, impulsada por la conservación de sus propios intereses, no podía menos que seguir la misma política de las otras dos naciones». Este juicio se articula a la actitud que siguieron esos países para contrarrestar la política colonial española: «La reina Isabel de Inglaterra y el rey Francisco I de Francia mantuvieron una constante protesta contra las donaciones de Alejandro VI y contra el Tratado de Tordesillas. Para ellos estos instrumentos no les eran oponibles (...). La lucha de intereses dio nacimiento al corso. Para hacer efectiva su protesta contra las concesiones pontificias, el rey Francisco I autorizaba - por patentes especiales- a sus armadores y capitanes, a realizar toda empresa guerrera contra españoles y portugueses en

12 El ensayo fue concluido en «Matayaya, República Dominicana. Mayo de 1930» y publicado en Madrid en 1931. Está dedicado $\propto \mathrm{A}$ mi querido amigo Don Rafael A. Espaillat, ex Secretario de Estado de Agricultura y Comercio», conspicuo representante del liberalismo político de entonces.

13 Ibídem, págs. 16-24. 
el Nuevo Mundo. Los gobiernos ampararon 'y protegieron la piratería para defenderse con ella de la absurda política ibérica. La lucha entre corsarios y españoles fue larga y heroica: duró hasta que España se decidió a abandonar el monopolio que había querido mantener en su comercio con América». ${ }^{14} \mathrm{Se}$ advierte en esta interpretación el criterio liberal que la anima, que no le concede a España sino una justificación inicial frente a la expansión portuguesa; mientras el ideal de la libertad de comercio se aseguraba el triunfo, siendo su vehículo la protesta de las naciones que competían con España por él, teniendo al corso y la guerra comercial por sus instrumentos.

Incluso la conferencia que pronunciara en 1938 sobre las devastaciones en la Isla Española (1605-1606), contiene elementos, retomados de las precisiones históricas que realizó Américo Lugo (1870-1952), ${ }^{15}$ que lo acercan al planteamiento de raíces liberales hostosianas. Aquí se le ve particularmente crítico frente a la política colonial española. Con la pasión que caracteriza su estilo, arremete contra la «absurda política comercial», correspondida a la postre con el absurdo histórico de las devastaciones. Todavía no ocupa la cuestión ideológica el centro de su argumento. Tal como él mismo señala en ese escrito, la causa fundamental es económica; el cambio de este criterio constituye uno de los puntos nodales de la metamorfosis de su pensamiento histórico, todavía sin producirse. Esa conferencia constituye el último de sus escritos en que se expresa la tradición liberal.

Relacionaba el contrabando y las maniobras de los extranjeros a la venalidad de los funcionarios y los pésimos sistemas administrativos españoles en sus colonias, lo que se agravaría con la introducción del sistema de flotas, pues a su juicio: «...se condujo a extremos increíbles la política comercial de puerta cerrada seguida por España en América. De hecho se declaró un riguroso y permanente estado de sitio en los puertos coloniales haciéndose

14 Ibídem, págs. 73-75.

15 Las precisiones históricas de Lugo se dieron a conocer a través de conferencias pronunciadas en 1932 en la sociedad «Acción Cultural», fundada por Peña Batlle. Fueron publicadas en la «Revista Bahoruco». 
del comercio hispano-americano una monstruosa institución de Estado, de sostenimiento casi imposible (...). A todas luces resultaba ya imposible sostener en el Atlántico y en el Pacífico la política italiana y medieval del Mediterráneo; no eran las mismas entonces las fuerzas contrarias, ni era el mismo el teatro en que debía desarrollarse una política tan absorbente y tan ambiciosa (...). Aunque parezca paradójico, es cierto que la extremada y rigurosa medida puesta en práctica por el Real Consejo al crear las Flotas de la carrera de Indias, produjo el acrecimiento del tráfico ilegítimo. La lucha cobró entonces proporciones gigantescas y no comenzó a decaer sino en 1713, cuando España, en el Tratado de Utrech, concedió, por primera vez, derechos sobre los beneficios del comercio hispano-americano». ${ }^{16}$

Si esto no fuera suficiente habría que señalar las consecuencias jurídicas que se desprendían de este análisis. En su Tratado de Sociología, Hostos, después de argumentar contra la política comercial española en términos similares como causante del contrabando en la isla, señalaba: «...esta burla de las leyes comerciales de la Metrópoli; lejos de ser delito común, era verdadero ejercicio de un derecho de necesidad». ${ }^{17}$ Peña Batlle por su parte, concluye: «...nada es más libre que el comercio. El contrabando, mejor que un crimen, era un imperativo de las circunstancias». ${ }^{18}$ En 1938, pues, todavía los conceptos de Peña Batlle sobre la situación colonial corroboran los puntos de partida de $1931 .^{19}$

Por el momento, conviene apuntar que a lo largo de la década de los treinta están presentes en Peña Batlle las preocupaciones históricas sobre la relación con Haití y la política comercial del imperio español.

16 Devastaciones de 1605 y 1606 . (Contribución al estudio de la realidad dominicana), Ciudad Trujillo, 1938; el trabajo fue agregado como introducción en Historia de la cuestión..., con algunas modificaciones; entre ellas el título que en 1946 pasó a ser: «Causas de la dualidad social y política existente en la Isla de Santo Domingo», págs. 5 y sigs. Hemos citado a través de esta última versión.

17 Hostos, E. M." de: Tratado de Sociología, en: Obras Completas, tomo XVII, La Habana, 1939, págs. 188-189.

18 Peña Batlle, M. A.: Historia de la cuestión..., pág. 13.

19 No sucedía así fuera del campo histórico, como tendremos ocasión de ver más adelante. 
A lo anterior hay que añadir una tercera preocupación que tocó a Hostos introducir como una categoría para pensar lo nacional: la noción evolutiva de lo social como base del desarrollo nacional. El concepto es recurrente en la obra posterior de Peña Batlle, aunque sustancialmente redefinido. Esta observación sugiere varios comentarios, pues el terreno de la problemática nacional y las categorías para pensarla provenían de la escuela hostoniana. ${ }^{20}$ En este sentido, la tarea de legitimación del despotismo no contaba con una base ideológica adecuada, situación que fue aclarándose ante sus ojos a medida que profundizaba en el conocimiento del régimen. Reconoció en ello una seria incompatibilidad entre la herencia ideológica y el régimen imperante que se mostraba agresivamente nacional. Sin duda esta circunstancia tuvo un peso considerable en la recusación global que hará de la obra de Hostos. En cierto modo esta recusación irá configurándose en una dialéctica con las demandas de la política despótica, que irán precisando el sentido global de su discurso hasta llegar a las matizaciones sobre el carácter particular, sui géneris, que la evolución histórica de dicha sociedad imponía a la democracia dominicana que él entendía no podía sino basarse en un principio fuerte de autoridad. ${ }^{21}$ Mas esa conclusión suponía una interpretación histórica conservadora que él quiso encontrar y finalmente pretendió atribuir a Américo Lugo.

Las dos preocupaciones históricas y la noción apuntadas, se resumían en la cuestión de los orígenes de la «dualidad social y política» existente en la isla. $\mathrm{Y}$ así quedará patente en las obras posteriores. Resolver esa cuestión era, en su criterio, hallar la solución teórica del problema nacional. Pero antes de ocuparnos de este nuevo punto de partida de la labor historiográfica de Peña Batlle, vale la pena precisar la imputación que hace este autor a Américo Lugo.

20 Tras nueve años de dictadura trujillista, Balaguer, Joaquín, en: Discusos escogidos, Santo Domingo, 1977, consideraba a Hostos como el forjador de la conciencia nacional: \&La cultura nacional -escribe en 1939 - es, en sus aspectos esenciales, obra de Hostos. (...). Las proyecciones de su genio iluminan, desde hace más de medio siglo, la conciencia dominicana», pág. 180.

21 Cfr. Peña Batlle, M. A.: Politica de Trujillo, Santo Domingo, 1954.

Pomo $X L V I I I$

38.-Anuario 


\section{UNA IMPUTACIÓN VICIOSA}

Américo Lugo abriría las puertas a la conservatización del liberalismo, pero no dio el paso decisivo. La relativización de sus concepciones democráticas en aras de constituir un verdadero estado nacional, por una parte, y la defensa de las raíces hispánicas de la nacionalidad dominicana, por otra, constituyen las dos direcciones en que se produjo la dicha apertura.

En rigor, la tarea de Lugo fue reconciliar el hostosianismo con el hispanismo. Esto no lo haría sin introducir serias ambigüedades en la comprensión de la relación entre pasado y presente, y en el continuum de categorías sociedad-nación-Estado en el sentido democrático desarrollado por el racionalismo hostosiano. ${ }^{22}$ Así lo advirtió Peña Batlle al señalar «la grave contradicción» que atraviesa su pensamiento político. ${ }^{23}$ Mas conferirle a esta evolución todo el contenido que sólo el propio Peña Batlle pudo dar a su noción hispanista, racista, autoritaria y antihaitiana de la nación dominicana, es una falsificación del pensamiento de Lugo. $\mathrm{Ni}$ siquiera es aceptable su conclusión de que la recusación del pensamiento de Hostos fue realizada ya por Lugo, ${ }^{24}$ puesto que si bien es cierto que él entendió que los conceptos históíicos del maestro debían ser rectificados en muchas partes, aprovechando el acervo documental que reunió en sus años de investigación en Europa, aún conservaba las categorías y la problemática misma de ese pensamiento. ${ }^{25} \mathrm{~A}$ tal punto, que la Historia de Santo Domingo que

22 Baste con señalar la insistencia de Hostos en desarrollar el espíritu gregario del pueblo dominicano, que veía en correspondencia con la necesaria descentralización requerida por el sistema político democrático. Véase Rodriguez Demorizi, Hostos..., y Hosios, E. M.a: Lecciones de derecho constitucional (1886), en: Obras completas, tomo XV, La Habana, 1939.

¿3 Peña Batlle, M. A.: Semblanza de Américo Lugo, en: Lugo, Américo: Historia de Santo Domingo. Desde 1556 hasta 1608. Edad Media de la Isla Española. Ciudad Trujillo, 1952, pág. XXII.

24 Tras comentar la labor de Lugo contra la ocupación en qua resaltó los rasgos hispánicos de la nación dominicana, aftrma: «La posición de Lugo resultaba, pues, negatoria de toda la influencia que hasia entonces había recibido él de su Maestro, el señor Hostos». Ibídem, pág. XXXII.

25 Lugo, Historia... Algunos juicios sobre la organización social, el comercio, la política, dan cuenta de ello, aunque también la obra está salpicada de otras nociones. Él racismo, matizado en función de la tesis de Vasconcelos, no deja de 
preparaba, publicada póstumamente en 1952, llevaba el sugestivo título de: Edad Media de la Isla Española. Ciertamente Lugo consideraba «inexacta» la apreciación que de la situación colonial de la sociedad dominicana hacía Hostos al juzgar «la enfermedad de carácter jurídico que aqueja a la República Dominicana» como señalara en su Tratado de sociología, sin dejar por ello de poner: el acento en el peso excesivo del aspecto militar y en el daño que los criterios comerciales de la Corona provocaron en la vida social de la colonia. ${ }^{26}$

Todavía más: Peña Batlle silencia dos elementos fundamentales, que no debió obviar al señalar los hitos del pensamiento de Lugo: el primero atañe al carácter mismo de la reconciliación realizada por Lugo, puesto que el movimiento hispanista no se produce sólo en la República Dominicana sino que tiene dimensiones continentales, y un sentido muy preciso que le otorga la confrontación con el imperialismo norteamericano.

Con motivo de la reacción latinoamericana ante la agresión imperialista del coloso del Norte, el proyecto sajón con que se reconocía la propuesta política hostosiana debió redefinirse. Desde este momento, la guerra hispano-cubano-norteamericana de 1898 y la secesión de Panamá de la República de Colombia, planteaba el problema de la oposición a los Estados Unidos de una manera urgente y dramática. Surgieron así autores: «...conscientes de que era necesario establecer una línea de defensa frente al avance imperial de la cultura anglosajona, que inevitablemente consolidaría la dominación económica, y hasta la política anexionista, que planteaban frontalmente los Estados Unidos». ${ }^{27}$

expresar, hasta cierto punto, una derivación de las posiciones hostosianas de tolerancia y tutelaje frente a las razas inferiores. Al juzgar esta obra habrá que. tomar en cuenia la advertencia que formulara el autor al iniciar su publicación en 1940: aAunque esto lleva el nombre de historia, no pasa de ser una compilación histórica basada en la cronología y en la divisiva regla clásica de lo secular y lo eclesiástico; y sólo tiene por objeto que otros escriban historia, seleccionando lo que en ella hubiere de histórico. Claro está que con el método simplista empleado aqui no se puede escribir una verdadera historia». «Clío», núm. XL, Ciudad Trujillo,

26 Lugo, Historia..., pág. 235-237.

27 Rama, Carlos M.: La imagen de los Estados Unidos en América Latina. México, 1981, pág. 25. 
A nivel continental el Ariel de José Enrique Rodó, desde su aparición en 1900 , se convertiría en la divisa del nuevo rumbo del liberalismo latinoamericano. ${ }^{28} \mathrm{Al}$ comenzar ese año Hostos publicará un artículo admonitorio, que al mismo tiempo que constituía una denuncia del imperialismo reclamaba un «esfuerzo supremo de desviación» por parte de los pueblos que se veían amenazados por éste. Había sonado la hora para la patria antillana de acceder por vías propias a la civilización, o todo su esfuerzo corría el peligro de perderse. ${ }^{29}$ En esa dirección La raza cósmica, 1925), de José Vasconcelos, será otro puntal del nuevo panorama intelectual que se configuraba desde inicios de siglo. Todos ellos influirán de manera decisiva en el pensamiento postrero de Lugo, sin que abandonase los criterios liberales y democráticos de su formación hostosiana. Lo más destacado fue su intento de definir con precisión la dirección del «esfuerzo de desviación» indicado por Hostos como única alternativa de los pueblos que no querían perecer. ${ }^{30}$ Para él, la tradición cultural hispana constituía el valladar más importante para frenar el influjo absorbente del imperialismo norteamericano. Sólo la oposición tajante que hizo a la postura pronorteamericana que exhibía Francisco J. Peynado (1867-1933), apoyándose pretendidamente en el maestro (Hostos), le confiere sentido progresivo a esta postura. Por si fuera poco, el Manifiesto de los intelectuales que escribiera en defensa de la República española, declara con toda nitidez el signo de su hispanismo. Este «olvido» tiene consecuencias, puesto que sin estos elementos, la posición hispanista de Lugo aparece fácilmente sin signo progresivo alguno que la distinga de las posiciones reaccionarias que campeaban en la España de los años cuarenta y cincuenta, cuando escribe Peña Batlle.

28 Aunque referido al período inmediatamente posterior, el trabajo de Arístides Incháustegui señala las influencias que tuvo esta obra desde inicios de siglo en el pensamiento dominicano, El ideario de Rodó en el trujillismo, «Estudios Socialies», Año 18, núm. 60, págs. 51-63, Santo Domingo, julio-septiembre 1985.

29 El artículo en cuestión es Civilización o Muerte, publicado en «Letras y Ciencias», Santo Domingo, enero de 1990. También en: Rodríguez Demorizi, Hostos..., tomo II.

30 Lugo, Américo: El imperialismo norteamericano, conferencia pronunciada en 1922 y publicada en varios editoriales del periódico «Patria», incluida en Julia, Julio Jaime: Antología de Américo Lugo, tomo I, Santo Domingo, 1976, págs. 147-155. 
El segundo «olvido» es todavía más relevante, pues involucra la actitud frente a Haití. A Lugo pertenece la iniciativa de formar una confederación de las dos repúblicas que comparten la isla. Lo hacía no en la etapa en que estaba «fatalmente imbuido de las ideas hostosianas» - para utilizar la expresión de Peña Batlle-, sino precisamente cuando casi ha completado su período de investigaciones en los archivos de Francia y España, esto es, en el año 1913. ${ }^{31}$ ¿Cómo es posible que llegara tan lejos? Peña Batlle no pudo recuperar desde el discurso reaccionario esta actitud de Lugo; por eso la silencia. Le tocará a un émulo suyo hacerlo. ${ }^{32}$ Tampoco en este punto Lugo se ha separado un ápice de las enseñanzas del maestro; entiende esa posición como un desarrollo lógico, como una consecuencia, de los planteamientos de Hostos, que en ningún momento proponía una fusión entre los dos pueblos que conviven en la isla. Ya en 1901 había expresado que «Haití y Santo Domingo tienen un deber común supremo: conservar la independencia de la Isla»; y agregaba: «sólo la confederación puede ayudarnos a cumplirlo». ${ }^{33}$ Que considerara válida esta propuesta en 1913, de cara a la amenaza imperialista, significa, casi sobra decirlo, que no había variado ese concepto.

Una referencia a las relaciones personales que entablaron Américo Lugo y Peña Batlle, corrobora en otro sentido lo que acabamos de ver a través de sus escritos. Dice Peña Batlle: «Fue en este momento, poco después de haber sido llevado a las barras del Tribunal Militar, cuando nosotros entramos en contacto con Lugo. Lo conocimos en su modesta e iluminada casita del Parque Duarte, rodeado de sus libros, de su pobreza, de su familia y de sus convicciones. Aquella casa era el centro de la ortodoxia na-

31 Desde Sevilla (en diciembre de 1913) escribe Lugo en su artículo Protesta: «¿Por qué no llama a Haití, su hermana de más edad y cordura y la abraza y le dice: quiero unirme a tí que has sido hasta ahora el único paladín de la soberanía de esta isia, en estrecha confederación que la garantice perpetuamente? (...). ¿Por qué no comprende que la confederación domínico-haitiana, en una palabra, es la única fórmula que puede salvar. junto con la soberanía de la isla, la nacionalidad patria?». Julia, Antología... tomo I, pág. 17.

32 Joaquin Balaguer ha querido recuperar en una perspectiva conservadora la referida propuesta de Lugo en su libro, La isla al revés, Santo Domingo, 1983!.

33 Lugo, Américo: A punto largo, Santo Domingo. 1901, págs. 239 y 244. 
cionalista dominicana, continuamente frecuentado por la juventud que se daba a estas cosas. A nosotros no nos atraía solamente las ideas políticas que allí tomaban cuerpo de expresión, sino también el encantado ambiente de tranquilidad y cultura que irradiaba en aquella casa. Nos seducían los restos de la biblioteca de Luga, su afición a la buena música, sus interminables conversaciones sobre arte, su erudición, tan amena y desleída, y sobre todo, las finas maneras del escritor y de su esposa, toda consagrada al culto del marido». ${ }^{34}$

Como hemos visto, Lugo dejó abierta una puerta a la conservación del liberalismo de matriz hostosiana que nunca cruzó; el tránsito hacia las posiciones derechistas lo cumplirá Manuel A. Peña Batlle, quien quiso acarrear el pensamiento del más representativo de aquella tradición democrática. ${ }^{35}$ Hacia 1923 conoció a Lugo, y enseguida despertó su interés por las materias históricas. Hay razones para ver a Lugo en las primeras conclusiones que esbozara Peña Batlle en 1931. Hasta es dable suponer que algunos de los libros que utilizara entonces pertenecieran a la biblioteca que tanto llamó su atención, cuyo recuerdo recoge entre los que la gratitud le inspiraba muchos años después. El impacto de las ideas de Américo Lugo debió ser suficientemente fuerte en la mente del joven nacionalista que era entonces Peña Batlle, ${ }^{36}$ como para que pagara tributo a las mismas. Por lo tanto, quien mejor nos habla de las ideas que sustentara Lugo en los años veinte, no es el Peña Batlle que emite juicios desde el statu quo de 1952 sino el que escribe todavía bajo esas influencias en 1931, 1932 y 1938.

Sólo a partir de entonces, cuando Peña Batlle acepta la participación en el poder que el propio Américo Lugo rechazara en

34 Peña Batlle, Semblanza..., pág. XXXVIII.

35 En marzo de 1945, escribe Lugo con pesar cómo contemplaba horrorizado el resultado del anconcebible menosprecio de los principios del liberalismo democrático, «substituido en la práctica por un régimen estatal capitalista que convierte a los pueblos en hatos de ganado; y se ve escarnecido por liliputienses superhombres que predican el sensualismo (...), la prescindencia de las normas jurídicas liberales (...), la destructiva violencia, la desapoderada ambición de poderío». Se refería a los regimenes fascistas y, por supuesto, al trujillista. Julia, Antología...

36 Sobre la militancia nacionalista de Peña Batlle, véase Mejía, Luis F.: Del Lilis a Trujillo, Santo Domingo, 1977. 
$1936,{ }^{37}$ se separa de él, y de las concepciones liberales y democráticas que el discípulo de Hostos representaba. Separados ideológicamente, nuestro autor no tardará en convertirse en el paladín del pensamiento histórico reaccionario de entonces. Ya sí está Peña Batlle en la situación que le deparó la integración al poder. Para darnos una idea de lo que esto significó, bastará tomar el testimonio de uno de sus compañeros de fortuna: «Peña Batlle alcanzó - son palabras de Rodríguez Demorizi- esta envidiable preeminencia en el arte y ciencia de gobierno: La de ser el más sagaz y decidido intérprete de las ideas políticas de Trujillo». ${ }^{38}$

\section{VALIDACIÓN IDEOLÓGICA DEL DESPOTISMO}

El período que siguió a su integración al poder es el más prolífico de su vida intelectual y el más importante desde el punto de vista de la transformación de su pensamiento. Durante casi diez años estuvo formándose, en pugna con las concepciones liberales originarias, en una constante trabazón con tareas políticas inmediatas, la conceptualización conservadora de la nación. Pese a que se vio precisado a sacrificar en bloque el sentido de sus conclusiones históricas y políticas precedentes, algunas de las publicaciones que verán la luz en este período las contienen formal. mente con la impronta singular de la transformación. No son ya los criterios hostosianos los que animan la matriz de sus preocupaciones. El vehículo de esta metamorfosis del pensamiento peña. batlleano en el campo histórico está dado por la asimilación de las corrientes historicistas y especialistas desarrolladas por. el pensa. miento irracionalista europeo entonces en boga. ${ }^{39}$

37 En carta dirigida al Generalísimo Rafael L. Trujillo, fechada en Ciudad Trujillo, 13 de febrero de 1936, en la que renuncia a escribir como «historiador oficial, la historia del pasado y del presente», reitera Lugo sus criterios el problema nacional. Julia, Antología.... tomo III, págs. 23-27. original.

38 Prólogo, en: Peña Batlle, Política..., pág. 8. Las cursivas están en el

s9 El propio Peña Ballle da cuenta de sus lecturas de Croce, Taine, Renán y otros historicistas. 
Aunque publicado en 1942, Transformaciones del pensamiento político ${ }^{40}$ fue escrito entre 1932 y 1933 y constituye el primer anuncio del nuevo derrotero de su pensamiento. Hay todo un debate acerca de si debe o no llamarse claudicación a su integración al poder, como quiera que procedía de una tradición que aparte de nacionalista se había destacado en la defensa de la democracia liberal. ${ }^{41}$ Probablemente en esa forma juzgaron su actitud sus contemporáneos y quizás repercutió en la afirmación de los criterios de quienes, al igual que Lugo, prefirieron cargar hasta la muerte con sus ideales democráticos. ${ }^{42}$ Acaso la pregunta más relevante se refiere al contenido de ese cambio que tan radicalmente ocasionó una ruptura en el modo de comprensión del fe. nómeno nacional. Si es así, entonces habrá que prestar atención a la valoración del poder en la tradición liberal democrática que fundara Hostos y la valoración del mismo que resultaba de las concepciones irracionalistas tal como las observaría Peña Batlle en el período entre guerras.

Otro exponente nutrido en la tradición democrática hostoniana y atento a los cambios que se producían en la posguerra fue Pedro Henríquez Ureña. Podría resumirse con una frase suya la valoración que persistía en aquella tradición: «El poder es siempre efímero», decía en su Utopía de América escrita en 1925. A la inversa, el poder cobraba a los ojos de Peña Batlle una trascendencia hasta ahora oculta para los que no pensaban sino en «la utopía de una revolución pedagógica». Para él tras la guerra de 19141918, los estados no serían más la expresión de un derecho particular como creyeron los liberales, sino instrumentos para el bienestar adecuado a un estado social dado. Este último correspondía entonces al de las clases organizadas con sentido corporativo de

40 Con un prólogo de Héctor Incháustegui Cabral (Santiago, 1942).

41 Aunque ampliado al conjunto de los intelectuales, el debate ha girado en torno a la flgura de Peña Batlle y la cuestión nacional. Cfr. las intervenciones en el Coloquio celebrado en el Instituto Tecnológico de Santo Domingo y publicado por $\ll E l$ Nuevo Diario», Papel de las generaciones. Suplemento «Intelecto», núm. 2, abril 1988.

42 Nolasco, Flérida de: Pedro Henríquez Ureña y otros ensayos, Santo Domingo, 1966. reflere cómo ila actitud radical de Lugo se mantuvo inquebrantable hasta sus últimos días. 
acuerdo con normas internacionales que el Tratado de Versalles habría propuesto por encima de la soberanía individual de las naciones; la creación de la Organización Internacional del Trabajo era una muestra de ese nuevo concepto supranacional que respondía a una evolución social moderna y requería de un nuevo tipo jurídico que lo expresara. Despojado de su halo jurídico, el estado habría quedado como simple instrumento de poder para ser empleado en favor de los ciudadanos colectivamente considerados. El derecho individual cedía ante el derecho corporativo. ${ }^{43}$ Ese instrumento de poder era lo que necesitaba el colectivo dominicano para colocarse «definitivamente en el carro de la civilización y de la cordura», como afirmara años más tarde.

En efecto, en el plano político el panorama nacional e internacional era realmente novedoso: el estado dominicano había rechazado con dosis crecientes de represión una tras otra las amenazas desestabilizadoras, dando muestras de una fortaleza inédita. $\mathrm{Al}$ incremento de la represión política y económica se agregó la matanza de miles de nacionales haitianos en territorio dominicano. El hecho, perpetrado por el régimen despótico en octubre de 1937, muestra hasta qué punto se vivía un clima de terror y xenofobia. ${ }^{44}$ Junto a ello, en el plano internacional, la derrota de la República española por el ejército franquista, y la reimplantación de la dictadura «nacional» con base en la ideología del falangismo; el auge obtenido por el nazismo y el fascismo en Alemania e Italia, respectivamente; todo ello aparecía devolviendo el espíritu corporativo y de cohesión nacional que el liberalismo individualista había fracturado en el orden burgués. ${ }^{45}$

Desde ese punto de vista, el sentido del sacrificio en aras

43 Peña Batlle, Transformaciones.... págs. 129-170.

44 Recientemente ha sido publicado el estudio de Bernardo Veqa, Trujillo y Haiti (1930-1937), tomo I, Santo Domingo, 1988. Entre los escritos inmediatamente posteriores a los hechos no deja de ser sintomático el de un connotado publicista del régimen que, glosando el famoso discurso de Peña Batlle, El sentido de una política (1942) en Elía Piña, encuentra el quid de la cuestión haitiana. Hernández Franco, Tomás: «Síntesis, magnitur y solución de un problema», «Cuadernos Dominicanos de Cultura», núm. 1, septiembre 1943, págs. 77-89.

45 La quiebra ideológica del liberalismo individualista era una cuestión eviden'e durante el período entreguerras, aunque desde antes lo señalaba la fuerza del pensaniento antidemocrático e irracionalista europeo. 
de un bien colectivo como era el estado, que serviría de instrumento para el «engrandecimiento» o la «reconstrucción nacional» aparecía, en medio de la crisis mundial que se prolongaba desde el año 1929, cómo la vía más expedita para lograr lo que el liberalismo no pudo conseguir en sus ensayos dominicanos: una nación moderna. ${ }^{46}$ En el plano intelectual, las filosofías irracionalistas, que apelaban a la «razón vital» o la «razón histórica» se prestaban a esta tentativa al mismo tiempo política e histórica. Bernardo Vega ha publicado párrafos de un discurso de 1935 en que Peña Batlle se muestra particularmente elocuente:

«De Trujillo me ha interesado en sus cuatro años de administración el sentido francamente 'nietzscheziano' que ha impreso al Gobierno y, como secuela, el hondo arraigo nacionalista con que ha desenvuelto sus gestiones de gobernante. Ni por inclinación, ni por temperamento, ni por educación libresca, yo soy un 'nietcheziano' del Gobierno, ni un nacionalista cerrado; pero después de haberlo pensado mucho, después de haber enfocado con reposo todos los aspectos de la situación, me formé el criterio de que las contundentes necesidades del momento en que el General Trujillo vino al Gobierno tal vez no hubieran podido conjurarse con éxito dentro de la ideología que hasta entonces sostuvieron nuestros hombres de estado, sino mediante la adopción de un sentido nuevo y extraordinario de Gobierno, que sólo un hombre singular hubiera podido imponer. Ese hombre fue Trujillo. Comprendí, sin esfuerzo, que era necesario reprimir ambiciones para contemplar el paso de aquel hombre a quien las circunstancias mismas habían tomado de la mano para colocarlo a la cabeza de los dominicanos en los precisos instantes en que la

46 La descomposición que reflejaba la posguerra de los años veinte y el estallido de la crisis económica mundial, no eran precisamente el panorama auspicioso que prometiera la «era científica» anunciada por los positivistas. Los movimientos fascistas nacionales, aunque conservadores, se presentaban como los verdaderos portadores de la grandeza nacional y aun de la modernización requerida por las circunstancias. No hay que olvidar que esos regímenes llevaron adelante la modernización indusirial deniro de un sistema que comprendía una legislación laboral «avanzada» respecto de las sustentadas por las economías ortodoxas liberales. Esta auspiciosa «modernización» económica y política desde el estado se denominó en la época «corporativismo». 
República, frente al cuadro pavoroso de la crisis, necesitaba fuerzas supremas y energías inagotables. Oponerse a la trayectoria de esas fuerzas y de esas energías, hubiera sido insensato y lo es todavía. Por eso me inscribí, hace apenas quince días en las nutridas listas del Partido Dominicano». ${ }^{47}$

A diferencia de otros intelectuales que no se plantearon el problema de su apoyo al régimen más que como una cuestión pragmática, Peña Batlle asume en términos ideológicos el contenido de las acciones del régimen despótico, las que encuadra en el marco de las transformaciones del pensamiento político de la época. Lo hacía con entera libertad de juicio, por esa razón debió advertir que hablaría sin cortapisas en ocasión de aquel discurso. ${ }^{48}$ Toda su energía se volcará en la construcción de una corriente ideológica adecuada al contenido de tal obra de gobierno, pues «dentro de la ideología que hasta entonces sostuvieron nuestros hombres de estado» no podía encontrar sus soportes. Alcanzó tal arraigo en la mente de este autor esta convicción que Joaquín Balaguer llega a afirmar que «Trujillo no parece haber comprendido cabalmente a Peña Batlle, ni haber dado a sus servicios el valor que realmente tuvieron». ${ }^{49}$

Bajo estas miras el pensamiento de Peña Batlle salta a la posición conservadora que caracteriza su obra de madurez. Sus concepciones políticas, estimuladas por los requerimientos del régimen despótico consiguen desplegarse con mucha más soltura que las concepciones históricas fueron a la zaga. En más de un sentido, la acción y el pensamiento político de Peña Batlle iluminaban e indicaban las tareas en el campo histórico. La matanza de haitianos, había convertido en cuestión de estado la historia de las relaciones fronterizas con Haití. Como contrapartida, la ideología nacionalista, en el sentido fanático, xenófobo, sólo campatible con las variantes irracionalistas del pensamiento europeo, lo era también

47 Vega, Bernado: Peña Batlle, Niettzsche y Trujillo: ol enigma de una claudicación, «Listín Diario», Santo Domingo, 3 de febrero de 1989, pág. 6.

48 «He HECHO LA PROMESA DE HABLAR CON CLARIDAD Y FIRMEZA Y CUMPIIRE CON MI PALABRA» mayúsculas en el original). Ibidem.

49 Balaguer, Joaquín: Memorias de un cortesano de la $\varangle$ Era de Trujillo», Santo Domingo, 1988, pág. 234.

Tomo XLVIII 
en lo que respecta a la consolidación y legitimación del régimen. Agudamente Peña Batlle captó que el momento reclamaba una visión histórica ajustada a ella, sin el compromiso liberal que hasta entonces exhibían los intelectuales al servicio del régimen.

La tarea presentaba dificultades reales en términos históricos que sólo podían afrontarse con un carácter profundamente convencido de esta necesidad y una sólida inteligencia que lo secundara. Peña Batlle fue representativo de ese carácter y esa inteligencia. No obstante, sus obras de este período expresan de diferentes formas esas dificultades.

Más arriba se ha mencionado la Historia de la cuestión fronteriza domínico-haitiana; pues bien, el tomo I de esta obra fue publicado en 1946. El libro realmente presenta los elementos todavía yuxtapuestos que conforman su visión histórica hispánica y antihaitiana. La introducción - ya citada - es un texto de 1938, con modificaciones, que no entronca sino superficialmente con la cita de Marcelino Menéndez Pelayo puesta como epígrafe. ${ }^{50}$ En cierto modo, el libro puede entenderse como muestra de la condición adversa que ha supuesto el diferendo fronterizo, el cual no se consigue resolver en forma definitiva por utilizarse para plantearlo criterios únicamente jurídicos, $\mathrm{o}$, incluso, geométricos. Le contrapone un criterio social que aparece en la introducción casi de manera aislada. El libro se justifica por el carácter que da al Tratado de Aranjuez, al considerarlo como el instrumento que había creado el único régimen fronterizo valedero entre las dos naciones, lo cual situaba a Haití como usurpador de casi una tercera parte del territorio que ocupaba antes de los acuerdos fronterizos llevados a cabo por Trujillo en 1935 .

Por otra parte, el cuerpo del libro - exceptuando la introducción, y algunas partes iniciales- está redactado en un estilo que recuerda las historias en forma de protocolos de inspiración positivista. Incluso, las matizaciones antihaitianas aparecen más como

50 La referencia la da el propio Peña Batlle: Menéndez Pelayo, Marcelino: Historia de la poesía hispanoamericana, Madrid, 1911. tomo I, pág. 312. El capítulo fue reproducido por la Universidad de Santo Domingo, junto al discurso de Fran. cisco Prats Ramírez, Homenaje a Menéndez Pelayo, Ciudad Trujillo, 1957. 
imputaciones que como desarrollos lógicos. Es el caso, por ejemplo, del capítulo IX donde trata de la cuestión del apoyo haitiano a los restauradores. Se detiene a explicar las consecuencias que tuvo en las relaciones dominico-haitianas la anexión a España: «Es necesario (...) tener en cuenta que este hecho contribuyó muy eficazmente a estrechar las relaciones entre dominicanos y haitianos, quienes, en presencia de un mismo peligro, optaron por olvidar, momentáneamente, sus odios y rencores para aunar sus esfuerzos en un legítimo propósito de defensa común. El presidente de Haití, Fabré Geffrard, dándose cuenta de la significación del momento por el que atravesaban los dos pueblos, empeñó toda su voluntad en favor de la aspiración dominicana de restaurar la secuestrada soberanía de la República, inconsultamente comprometida en empresa de éxito dudoso». Para superponer inmediatamente motivos que no necesitaban de los anteriores: «...desde luego, el estadista haitiano no obedecía a impulso de un altruismo sentimental. Al enfrentarse a España y ayudar a los insurrectos dominicanos hasta el punto de comprometer la suerte de su propio Gobierno, cumplía una finalidad básica de la política nacional haitiana: descoyuntar el sentido hispanista de la nacionalidad dominicana». ${ }^{51}$

Para quien está leyendo el libro, esta conclusión viene a ser una afirmación que no sale de ningún argumento anterior, incluso, luce por su tono como un añadido. Y, en efecto, si el texto no fue reescrito en su totalidad — como deja ver el prefacio de su autor-, la sustentación de lo que hemos subrayado en la cita anterior no se encuentra desarrollada en él y, probablemente, ni siquiera -en ese momento- en la cabeza del autor. Acaso por las razones que hemos mencionado arriba, consideró necesaria la publicación de este libro, para lo cual debió introducir algunos cambios. El párrafo citado es, seguro, uno de los intercalados.

No obstante la debilidad argumentativa de la obra, La Historia de la cuestión fronteriza domínico-baitiana tiene el valor de presentar los nuevos puntos de partida para construir la concepción de lo nacional. El autor aprovecha la publicación de los materiales

51 Peña Batlle: Historia..., págs. 149 y sigs. 
. zunidos en 1928, para enunciar sus propósitos en el ámbito histórico; de esta manera, en las «Palabras previas» recalca este objetivo: «La historia de nuestro país está estrechamente ligada a sus problemas fronterizos. Para los dominicanos, la frontera, considerada no como expresión geográfica, sino como un estado social, es elemento integrante de la nacionalidad y envuelve en sí problemas sustanciales de los cuales depende en enorme proporción el porvenir de la República. Consideró muy útil, en consecuencia, profundizar en el estudio del asunto, para que nos sea posible afrontar estos problemas con cuidado 'y conciencia, libres de prejuicios, pero debidamente informados sobre el proceso y evolución de los hechos que han determinado en el curso de nuestra historia las situaciones especiales por que ha atravesado la cuestión fronteriza y para poder estimar, con el conocimiento de causa requerido, las necesidades que puedan derivarse de tales situaciones». ${ }^{52}$ Mas el propósito que anuncia, sólo más tarde -y no en el interior de ese libro - tendrá ocasión de materializarse.

La obra que cierra este período de transición hacia sus concepciones maduras es La rebelión del Baboruco. ${ }^{53}$ Aquí Peña Batlle se revela como sesudo polemista, al mismo tiempo que avanza en la comprensión de las concepciones jurídicas que animaron la implantación colonial española en sus orígenes. Reemprendía el camino de 1931, pero ahora con vistas a desentrañar las raíces hispánicas de la nacionalidad dominicana. El capítulo VII constituye un alegato jurídico sobre el derecho a la sublevación que asistía a Enriquillo sobre la base de las doctrinas cristianas entonces vigentes que los dominicos de la Española convirtieron «en programa de acción política para las Indias». Ese programa estuvo en la base de la sublevación del cacique sin que se tratara de un levantamiento fundado en el «principio de independencia nacional propiamente dicho». ${ }^{54}$

«En el terreno científico y doctrinario -continúa diciendo más adelante- fijó el padre Vitoria conclusiones definitivas sobre

52 «Palabras Previas». Ibídem.

53 Ciudad Trujillo, 1948.

54 Ibidem, pág. 92. 
la extensión del derecho de los indios (...). En la doctrina genial del insigne Maestro de Salamanca no cabe dudarse sobre el principio básico de la igualdad entre indios y españoles 'como si se tratase de naciones europeas' (...). De la igualdad natural, al estilo cristiano, de todos los hombres, cual que sea su condición social o étnica, se desprende con gran facilidad el postulado vitoriano de que también son iguales las naciones en que aquéllos viven organizados, aunque se trate de pueblos no creyentes ni civilizados en la forma europea (...). Aplicando concretamente toda la teoría al caso concreto del Bahoruco, Fray Bartolomé reconoce específicamente a Enriquillo como sujeto de Derecho Internacional. Es esta una premisa que debe tenerse muy en cuenta, porque de su consistencia teórica dependerán en mucho nuestras conclusiones». ${ }^{55}$

Llama la atención cómo se conjugan en esta obra las doctrinas jurídicas de Salamanca con las que representará, más adelante, el nacionalismo protestante: «De Vitoria —escribe- pasó el legado al insigne holandés Hugo Grocio y de éste a la inquietud de hombres y pueblos deseosos de encontrar el eje de sus relaciones». ${ }^{56}$ Pero su significación sobrepasa nuestro asombro.

Rebatiendo los conceptos de fray Cipriano de Utrera, Peña Batlle advirtió una brecha desde donde reconstruir las bases de la formación nacional dominicana. Este punto remite, en particular, al terreno ideológico, donde radicaba de manera fundamental el obstáculo más importante de la conceptualización conservadora. Había estado bregando en esa tarea convencido de la necesidad y ahora encontraba la posibilidad de llevarla a cabo. La resistencia de Enriquillo, cuya base estuvo en el «programa político de los dominicos», aunque no constituía «propiamente» una reivindicación nacional, la anunciaba; era su presagio.

En esta «tradición» que parte del pensamiento colonial en la isla se inaugura, a su entender, una ideología nacional dominicana, preliberal, conservadora, libre de las influencias racionalistas francesas. No importa que en aquel momento el intento de resis-

55 Ibidem, págs. 94-95. Subrayado en el originan

56 Ibídem, pág. 96.

Tomo XLVIII 
tencia encabezado por Enriquillo se saldara con el fracaso. Ello constituiría una de las tantas adversidades con que ha tropezado la formación nacional. Ni siquiera que el humanismo cristiano de los dominicos asumiese contenidos erasmistas, puesto que a la postre sus doctrinas fundaron los justos títulos de la dominación española en Indias; y aún se les puede considerar fundidas en el bloque ideológico que saldrá del Concilio de Trento y la Contrarreforma. A tal punto llega su contento que adoptando en su argumentación la doctrina de Santo Tomás, según la cual la base de la legitimidad del poder reside en el bien común, ¡recrimina por «impolítica» la matanza perpetrada por Ovando contra los aborígenes! ${ }^{57}$

Después de 1948, en el pensamiento peñabatlleano la formación nacional dominicana se asentará en perfecta correspondencia con el tradicionalismo, sin los abigarramientos de este período transicional. En lo sucesivo se aclara la dimensión global de la recusación del pensamiento hostosiano, que nadie hasta él había emprendido; pues está claro que no se le puede dar esa entidaid al señalamiento de «inexactitudes» que había realizado Lugo al final de los años treinta e inicios de los cuarenta. Esa recusación trascendía el marco de las necesidades políticas del momento, pero aseguraba una larga trayectoria al dominio burgués despótico, aun cuando se planteara su recambio.

\section{AJuste de CUENTAS CON LA heRENCIA hostosiana}

Fruto de los diferentes esfuerzos que hacía desde su doble situación de político e historiador, por concretar un pensamiento histórico coherente con las características del régimen y de la ideología burguesa de la época, concibió con claridad una empresa colosal que marca el inicio de la última etapa de su pensamiento. Ella implicaba dos tareas, la una en sentido negativo: la impugnación de la tradición hostosiana; y la otra en sentido positivo:

57 Cfr. Ibídem, pág. 216. 
la reconstrucción histórica de una ideología nacional sobre bases conservadoras. Dos caras de una misma moneda.

El criterio con que abordará la segunda tarea lo había formulado en 1945, rebatiendo las opiniones del ministro cubano de Relaciones Exteriores, doctor Jorge Mañach. Aparte del antihaitianismo visceral que refleja, lo más relevante, en cierto modo, es que la formulación de ese criterio se inspira en la misma lógica con que Hostos llamó la atención frente al imperialismo norteamericano. Por supuesto, Peña Batlle le confirió al planteamiento un contenido aberrante. El texto no tiene desperdicios:

«...los dominicanos — dice en su carta a Mañach - hemos vivido frente a un dilema aterrador, de vida o muerte: nosotros o nos organizamos consistentemente para la civilización o perecemos absorbidos por esos factores negativos de que le hablo más arriba. Por no haber podido hasta ahora dar suficiente consistencia económica y social a la nacionalidad perdimos mucho más de la tercera parte del territorio de la isla que fue nuestra en el principio y que hoy compartimos con los causahabientes de filibusteros, ladrones y malhechores de toda laya. Los errores políticos de la España decadente y estadiza del Conde Duque los estamos pagando nosotros todavía con sangre y sudores. Francia canalizó contra España las fuerzas proditorias del bucanerismo y sentó reales en la isla desde el segundo tercio del siglo XVII para afincar allí una colonia que ni aprendió a hablar francés. Desde entonces se inició en la isla de Santo Domingo una lucha tremenda entre dos fuerzas sociales opuestas cuya determinación no es previsible todavía». ${ }^{58}$

Huelga decir que este criterio resulta absolutamente inaceptable para Eugenio María de Hostos y Américo Lugo, por sólo mencionar dos figuras de la escuela hostosiana que influyeron -el primero con sus obras y el segundo con sus obras y su persona- decisivamente en la formación inicial de Peña Batlle. Re-

58 Peña Batlle, Carta al Dr. Jorge Mañach, en: Política..., págs. 95-96.

Tomo XLVIII

39.-Anuario 
chazo intelectual y moral que la más ligera confrontación de sus obras advierte. De tener la oportunidad, Hostos le hubiera devuelto la aseveración que hace en esa misma carta, cuando dice que: "Con la única excepción de Eugenio M. ${ }^{a}$ de Hostos, maestro amado de los dominicanos, las cabezas señeras del Continente no han mirado la encrucijada en que nos debatimos los hijos de esta tierra». ${ }^{59}$ Se la hubiera devuelto por falsa y gratuita. Hostos no vio ni podía ver de esa manera.

Para tranquilidad de sus restos, Peña Batlle lanzaría un conjuro contra la obra de Hostos equiparable al odio que sentía por el pueblo haitiano. Recusación que era un corolario de la tarea pendiente de fundar una noción conservadora de la nación dominicana.

Son bien conocidos los términos del famoso prólogo al libro de Antonio Valle Llano. ${ }^{60}$ Introduce su diatriba acusando a Hostos de superficial, de no haber contribuido a acrecentar el «caudal de conciencia» hispanista. El magisterio de Hostos se había iniciado cuando «estaba en crisis extrema de valores la experiencia social dominicana»; en razón de esta crisis, resultaba que no podía ser «ningún medio más incauto que el dominicano para confrontar la doctrina del Maestro». Esa crisis tenía su origen en Haití: «Desde 1801 estuvimos sujetos a la influencia haitiana que llegó a su clímax durante los veintidós años de Boyer». Y después de señalar el contexto, continúa con la enumeración de los cargos: «Filósofo materialista (...). Político liberal (...). Anticatólico (...); visible sentimiento de simpatía calvinista (...), admiración por los movimientos religiosos y políticos de La Reforma. (...) grandes líneas del pensamiento político hostosiano se desprenden de la Revolución Inglesa y del enciclopedismo francés del XVIII (...). Ni estudió ni comprendió los problemas de este país y los miró siempre imbuido en sus sentimientos antihispánicos (...). Apasionada (y) desconcertante justificación de la influencia haitiana en Santo Do-

59 Ibídem, págs. 94-95.

60 Peña Batlle, M. A.: Prólogo, en: Valle Llano, Antonio, S. J.: La Compañia de Jesús en Santo Domingo durante el periodo hispánico, Ciudad Trujillo, 1950, págs. 1-15. 
mingo. En su sañuda desobediencia a lo español, el señor Hostos nos prefería haitianos». ${ }^{61}$

Y luego del maestro, seguían sus enseñanzas: «Ni la ciencia ni la razón son en sí elementos vivos de un verdadero ideal nacional. Eso dejó de discutirse desde hace muchos años. La Escuela Normal formó varias generaciones dominicanas, pero no creó un auténtico programa de recuperación colectiva. No enseñó a los dominicanos a gobernarse ni a conducirse con sentido corporativo». ${ }^{62}$

Sólo faltaba hacer auto de fe con Hostos y el hostosianismo.

El resto de los intelectuales trujillistas, la mayoría de los cuales venían torciendo y retorciendo los planteamientos democráticos de la escuela hostosiana en un acoplamiento grotesco con el despotismo, se solazaba en esta recusación. Si embargo fue el caso que a la altura de los años cincuenta era muy difícil echar a andar una nueva construcción ideológica. A lo sumo se adoptó un discurso que aceptaba nadar en las dos aguas, por lo que la ideología trujillista siguió presentando las contradicciones y falsificaciones que la caracterizan. ${ }^{63}$ Fuera de ese inconveniente, es probable que operaría la incapacidad intelectual de muchos que se hacían pasar por tales medrando a la sombra de la dictadura. Pero lo cierto fue que entre las dos cosas dieron al traste con la recusación de Hostos que Peña Batlle captó como un elemento primordial de un reactivamiento ideológico propio de la dictadura; la que en su desfase no tuvo solución de continuidad. ${ }^{64}$

En 1956 el diario «El Caribe» ${ }^{65}$ tomó el pulso de la impugnación peñabatlleana, por lo menos en lo tocante al punto de la

61 lbídem, págs. 9-10.

62 Ibídem, págs. 12-13. El subrayado es nuestro.

63 Un ejemplo puede verse en el discurso de Pedro Troncoso Sánchez, Esł piritualidad y cultura del pueblo dominicano, «evista Dominicana de Filosofía», Año, I, núm. 1, Santo Domingo, enero-junio 1956, nágs. 5-29; donde se exalta el tradicionalismo de Peña Batlle a propósito de la cullurara y lo nacional y se ataca el liberalismo (págs. 11-12) mientras a propósito de lo mismo se exalta la obra: de Hostos (pág. 23).

64 Sobre el aparato ideológico trujillista, véase Cassá, Roberto: Capitalismo..., cap. IX.

65 La influencia de Hostos en la cultura dominicana. (Respuestas a la encuesta de El Caribe). Ciudad Trujillo, 1956.

Tomo XLVIII 
«influencia cultural». Casi todos (con la excepción de Andrés Avelino y Robles Toledano) se inclinaron por una interpretación que colocaba a Hostos habiendo cumplido con una tarea histórica, en su tiempo, positiva; aunque Trujillo, por supuesto, representaba una situación superior.

Peña Batlle había sido crítico frente a la inconsistencia de la «dialéctica» - como él la denominaba- de sus amigos y otros servidores del régimen, quienes se empeñaban en compaginar el liberalismo hostosiano con el trujillato. Más de una vez llamó la atención sobre este particular. Casi como una ironía, tras la muerte de Peña Batlle, Rodríguez Demorizi, haría el último intento por colocar a Peña Batlle como uno más de ellos, compartiendo el grotesco dualismo que tanto había criticado:

«...la impugnación de Peña Batlle es el mejor tributo que hoy puede rendírsele al insigne Educador; revisar su obra, vivificar lo permanente de esa obra; extraer de ella lo útil y valedero, constituiría una nueva modalidad del hostosismo. Peña Batlle inició la bella empresa. Al Hostos de ayer podrá oponerse el Hostos de hoy y de mañana...». ${ }^{66}$ ¡Hasta ese extremo llegaba la «dialéctica» de sus amigos!

A la hora de escribir aquel prólogo Peña Batlle veía con claridad la otra cara de su empresa ideológica. Y, en efecto, al final del mismo enuncia la tarea positiva:

«...una conciencia social, no podrá crearse en Santo Domingo por sistemas contrarios a la idiosincrasia hispánica y católica del pueblo dominicano. Si deseamos verdaderamente crear un ideal de civilización para vincular en él los factores de nuestra expresión nacional obligados estamos a exaltar aquellos dos valores esenciales de nuestra constitución. Hacer otra cosa equivaldrá a secar las raíces de nuestro espíritu». ${ }^{67}$

66 Ibídem, págs. 14-15.

67 Peña Batlle, Prólogo, págs. 14-15. 
FUNDAMEN'TACIÓN HISTÓRICA CONSERVADORA

La isla de La Tortuga y El Tratado de Basilea... ${ }^{68}$ son obras complementarias. Persiguen un mismo objetivo y siguen un mismo plan. Difieren en el período que abarcan y en la calidad del tratamiento de las fuentes documentales y bibliográficas. En realidad, sólo la primera es un verdadero resultado de investigación histórica, mientras la segunda queda a nivel de hipótesis como ensavo. Por esta razón La isla de la Tortuga constituye el remate de la tentativa peñabatlleana en el campo historiográfico; y en la República Dominicana, acaso la obra cumbre del pensamiento conservador en esta materia.

Con el pretexto de estudiar La Tortuga, construyó toda una teoría del desenvolvimiento histórico dominicano y la formación nacional acorde a sus prejuicios antihaitianos e hispanistas.

En la elección de la pequeñita isla de La Tortuga, convergen diferentes razones: desde temprano se interesó por los problemas del comercio de contrabando y las devastaciones de Osorio; el nexo entre estas últimas y la ocupación occidental de la isla por los franceses ya había sido establecido en la historiografía. ${ }^{69}$ Los documentos de la Recopilación Diplomática realizada por Américo Lugo, que Peña Batlle había dado a la publicidad, ${ }^{70}$ contenían prolijamente los detalles de esa historia, junto a otros que en esos años había dado a la publicidad Emilio Rodríguez Demorizi, gracias al trabajo realizado por fray Cipriano de Utrera; $"$ era material de primera mano procedente de los archivos franceses y españoles, respectivamente. Ellos, sin embargo, si bien son con-

68 Peña Batlle, M. A.: La isla de La Tortuga. Plaza de armas, refugio y seminario de los enemigos de España en Indias, 2." ed., Madrid, 1977. La primera edición apareció en República Dominicana en 1951; y del mismo autor, El Tratadó de Basilea y la desnacionalizáción del Santo Domingo español, Ciudad Trujillo, 1952.

69 Véase Sánchez Valverde, Antonio: Idea del valor de la Isla Española, Cuidad Trujillo, 1947; Monte y Tejada, Antonio del: Historia de Santo Domingo, 3.a ed., tomo II, Ciudad Trujillo, 1952; García, José Gabriel: Compendio de $l a_{1}$ Historia de Santo Domingo, 4.a ed., tomo I, Santo Domingo, 1968.

70 Colección Trujillo. Publicaciones del Centenario de la Rejóiblica. Serie III, vol. 1, tomo 13, Recopilación diplomática, 1640-1701. Santiago, 1944.

71 Rodríguez Demorizi, Emilio: Relaciones históricas de Santo Domingo, vol. III, Ciudad Trujillo, 1948. 
diciones básicas, no constituyen razón suficiente para decidirse por el tema.

En realidad, La Tortuga tiene todo un valor simbólico. En primer lugar, ante la mirada conservadora de Peña Batlle, en los poco más de cincuenta años que forman el ciclo de la historia de esta islita en el siglo XVII se resume, hecho realidad, el contenido de todas las metáforas sobre el quebrantamiento del orden, de la vida sin sujeción a la autoridad, sin principio de orden alguno; esa sociedad que no puede ser nación, reúne todo lo vituperable de la existencia humana desordenada, abandonada al libre albedrío. Para Peña Batlle, aquí reside una parte del pecado original de la nación haitiana. En segundo lugar, lo que fue la vida de los hombres de La Tortuga constituía, en alguna manera, un referente de una premisa básica del pensamiento liberal: el «hombre natural» de Rousseau. La disputa que el pensamiento conservador sostiene con el liberalismo y el racionalismo tiene allí en su favor, a los ojos de Peña Batlle, un argumento irrefutable. Por último, allí el enfrentamiento de los poderes europeos alcanzaría, a su juicio, la altura de la epopeya, para no decir que cobraría vida el mismo don Quijote en la figura de Montemayor de Cuenca, arquetipo dominicano. $Y$ aún más: la islita menospreciada, se convertiría en el talón de Aquiles del incontrastable Imperio español... cual «piedra que desecharan los que construyeron».

Si a este valor simbólico se agrega el hecho de que en ese punto del Caribe se dieron cita las naciones que disputaban a España el predominio comercial y sus posesiones coloniales, siendo un contrafuerte singular de estos poderes a lo largo del siglo XVII; siglo cuyo saldo en Europa fue la hegemonía de la monarquía francesa y en el Caribe la formación de hecho de la colonia francesa, que está en el origen de la República de Haití, no cabe duda de que la elección había sido acertada.

La tesis de La isla de la Tortuga es que la nación dominicana se formó desde el mismo siglo XVI bajo el influjo estatista del imperio español. A ese influjo se debe además la preponderancia de la civilización moderna occidental y cristiana. El estado conformó de una vez y para siempre el sentido hispánico y católico de 
la nación dominicana. Sujeta al estado para sobrcvivir, la nación no pudo adquirir rasgos peculiares como resultado del desarrollo de la sociedad en un medio diverso. De esa manera la nación dominicana se define como «un rincón espiritual de España». Lo que se haya perdido de los rasgos originarios se debe a la inci, dencia perniciosa de la decadencia del imperio en general y en particular de la colonia occidental (Haití).

Sin restar originalidad al concepto de nación que desarrolla en este libro, no hay duda de que Peña Batlle se inspira directamente en las tesis tradicionalistas de Menéndez Pelayo y en la idea de la «hispanidad» popularizada por el falangismo. ${ }^{72}$ En la Historia de la cuestión fronteriza... ya ha colocado de epígrafe la cita con que el santanderino concluye su capítulo sobre la «Poesía en Santo Domingo». ${ }^{73}$ Pero el leitmotiv de esa obra no corresponde al sentido profundo que el concepto del tradicionalismo implicaba; había entonces una relación exterior entre el contenido, la cita y el libro propiamente dicho, puesto de manifiesto por la inserción de la conferencia de 1938 como introducción. ${ }^{74}$ Pero en este otro libro, aunque sin mencionarlo para este propósito, hay una compenetración con el sentido de aquella cita. Lo que en la primera ocasión había quedado como expresión de propósito, ahora quedaba cumplimentado.

En suma, la concepción peñabatlleana de la nación dominicana es rigurosamente el desarrollo de la tesis de Menéndez Pelayo según la cual España, «...Martillo de herejes, Espada de Roma, luz de Trento y cuna de San Ignacio (...), en aras del interés católico y cultural del mundo y en defensa de las libertades nacionales, se desangró y arruinó a sí misma en la época de su mayor grandeza». «Pero fuimos el único pueblo de Europa que cuando todos los demás volvían de una manera o de otra la espalda a la tradición medieval, supimos mantener la continuidad bistórica, salvando la uridad espiritual de Occidente, por lo menos en e!

72 La diciadura de Primo de Rivera intentó galvanizar un proyecto nacional apoyado en estas tesis junto a las elaboraciones de Ramiro de Maeztu.

73 Supra, núm. 50.

74 Peña Batlle no completó el proyecto anunciado de un segundo volumen de la"Historia de la cuestión fronteriza. 
Mediodía y trasplantarla a otros continentes. Nuestra muerte fue la salvación de Europa y la vida de infinitos pueblos de América. Quedamos para lección y ejemplo del mundo por nuestra postura gallarda y nuestra manera típica de realizar la idea imperial a base de una Monarquía cristiana (...)». ${ }^{75}$

El hecho de estar inspirado en esta tesis y en el contexto político anotado, da pie a una discusión - todavía pendiente- sobre las posiciones de principio, filosóficas y políticas, de Peña Batlle, aunque éstas no sean elaboraciones suyas. ${ }^{76}$ Mas lo que nos cumple tratar aquí es el entramado de la concepción histórica nacional que constituye el objetivo central de las obras publicadas por Peña Batlle en este último período.

Veamos, «sin digerir», como lo expone el autor:

«La independencia dominicana (...) comenzó a producirse dos siglos antes de que despertara en estas tierras una conciencia política de autoeterminación (...).

«Durante más de dos tercios de los quinientos luchamos contra la Reforma. El contrabando de los productos de la isla fue un activo agente de la lucha del calvinismo contra los poderes católicos. (...). A fines de la centuria la isla de Santo Domingo vivía un penoso período de inquietud en el que estuvieron a punto de perderse nuestra raíz hispánica y nuestra tradición católica. En el transcurso de los seiscientos vivimos en constante estado de guerra con bucaneros y filibusteros, luchando contra el individualismo crudo y descarnado que dio origen a todo el sistema capitalista moderno. (...). Los setecientos los pasamos en un cruento y prolongado esfuerzo para obtener la divisoria fronteriza que nos salvara de la penetración francesa. En 1795 nos pagó España aquel denodado esfuerzo vendiéndonos a Francia como si fuéramos un 'hato de bestias', en el momento preciso en que triunfaban en

75 Menéndez Pelayo, Marcelino: Historia de los heterodoxos españoles, tomo VII, Madrid, 1933, págs. 513-515; apud, La conciencia española. (Recopilación de Antonio Tovar). Madrid, 1948, págs. 262-263.

76 Fernando Ferrán ha llamado la atención sobre la necesidad de estudiar la influencia del historicismo y otras corrientes en el pensamiento social dominicano. 
aquel país las ideas por las que habíamos sufrido nosotros todas nuestras vicisitudes. Los ochocientos nos trajeron el predominio de los esclavos y la influencia de las ideas y los sistemas del materialismo y el positivismo francés, traducidos en más de cincuenta años de opresión haitiana, y en otros cincuenta años de desconcierto y turbulencias derivados de la influencia de Haití». ${ }^{77}$

Un momento culminante de la consolidación nacional se relaciona con La Tortuga:

«Durante los once años del gobierno de D'Ogeron se desarrolló el más espantoso drama por la conservación de la isla de Santo Domingo. Los dominicanos, celosos de su heredad, resistieron hasta extremos increíbles el empuje de los bucaneros y de los colonos franceses para adueñarse de la isla. La epopeya no ha sido todavía reseñada en toda su magnitud, pero de sus resplandores surgió nuestro país en sus proporciones geográficas actuales. En aquella lucha sin cuartel, de insospechada ferocidad, se templó para siempre el temperamento colectivo y el espíritu nacional de los dominicanos. Después que Peñalba abandonó La Tortuga se perdió definitivamente el contrafuerte en la lucha por el predominio marítimo y comenzó a desintegrarse el imperio de España en América como elemento de supremacía comercial. Pero al mismo tiempo se inició el conflicto social, todavía existente en Santo Domingo». ${ }^{78}$

Otro momento marcado por el Tratado de Basilea inicia el período de dislocación; tras lo cual se impuso el instinto de conservación:

«La única manera de llegar alguna vez a la independencia la vieron los dominicanos de aquella época en la conservación de sus formas sociales tradicionales. Nuestra independencia tiene configuración conservadora. Es el resultado de un fenómeno de introspección Social. El contacto con el materialismo haitiano, nos ena-

77 Peña Batlle, El Tratado.... págs. 20-24.

78 Peña Batlle, La isla..., págs. 2£6-227.

Tomo XLVIII 
jenó muchas de nuestras modalidades originarias, pero lo recóndito de nuestras esencias hispánicas se mantuvo y se mantiene inalterado». ${ }^{79}$

En resumen: «La independencia dominicana representa un movimiento social de introspección. Continuamente nos hemos visto obligados a volver hacia atrás — por vías de conservación - para no perder nuestras características permanentemente amenazadas por el imperialismo calvinista, por el materialismo y por el africanismo básico de la formación social haitiana». ${ }^{80}$

Analicemos este concepto. Tal como aparece desarrollado en sus últimos trabajos, el concepto de nación implica para Peña Batlle una doble dimensión: una dimensión material y otra espiritual. La primera está sometida a la contingencia del cambio en el tiempo, mientras la segunda es de carácter inmutable, eterno; de ahí la preeminencia de esta última sobre la primera. Ambas están unificadas por una fuerza trascendental que tiene expresión en el Estado.

1. La primera de esas dos dimensiones está compuesta por la sociedad-territorio. Aquí comienza a hacerse particular su concepto de lo nacional: la insistencia en el autorreconocimiento, mcdiado por el interés que despierta en el hombre el territorio didonde vive y comparte con los de su mismo colectivo, está en la base de esta noción. Aquél da pie a la interiorización de la unidad del colectivo con el territorio: se trata de un vínculo «entrañable». No puede haber fractura en esta noción: territorio y sociedad quedan forzosamente implicados bajo una misma unidad analítica; separarlos es falsear la concepción de Peña Batlle de la «vida social». En efecto, la sociedad-territorio es la que está sometida «a la inestabilidad», a «la inquietud»; es por aquí que se introduce todo el dinamismo social que cabe en el concepto de nación de Peña Batlle, quien atribuye carácter de ley a ese tipo de cambios dentro de esta dimensión material: «...La ley fundamental, el elemento básico de nuestra formación social son la inestabilidad

79 Peña Batlle, El Tratado.... pág. 37. Subrayados en el original.

80 Ibídem, pág. 24. 
y la inquietud. La nacionalidad dominicana se integró en un inconfundible ambiente de recelo y desconfianza que nos obligaba a vivir sobre el escudo en función constante de combate $y$ vigilancia». ${ }^{81}$

Con el establecimiento de esta relación unívoca entre sociedad y territorio se asegura, de un lado, la confinación de lo social al interés imperial de conservación de sus posesiones americanas y, de otro lado, la supeditación de lo social a lo nacional, en cuanto la equivalencia de ambos extremos coincide en el término central dado por el territorio. De ahí también que identifique la frontera como estado social, el cual habría evolucionado desde una situación «completa» configurada en el siglo XVI, hasta la situación «mutilada» de mediados del siglo XVII. Ambas situaciones representan estados sociales distintos.

A propósito de la consulta promovida por el presidente de la Audiencia de Santo Domingo sobre el futuro de la guarnición destacada en La Tortuga tras el rechazo de las fuerzas inglesas en 1655 , Peña Batlle caracteriza esa evolución. Los participantes de aquella reunión tenían claro que La Tortuga era otra cosa que la costa norte de la isla, y no iban a arriesgarse por algo que ya no reconocían como propio: «La mutilación de Osorio babía cobrado ya carácter social en 1655». Bayajá, Puerto Real, Govaines o La Tortuga, ya no eran parte de lo «entrañablemente dominicano». Para los dominicanos de entonces no cabía el sacrificio por aquellas posesiones, su sangre correría «solamente en defensa de la heredad local, de la patria chica, de lo que nos dejó a nosotros la disgregación del Imperio». ${ }^{82}$

Correspondiente a esta sociedad-territorio, está un puebloterritorio o una masa-territorio, vaciados en los moldes culturales, las «formas sociales» de. que nos habla Peña Batlle. En efectc, se violenta toda la conflictividad social para reducirla a la constitución de un «frente nacional» permanente contra la amenaza primero de los «enemigos de España», luego trocados por «el enemi-

81 El Tratado..., pág. 19.

82 La isla..., págs. 201-2020. Subrayado en el original. 
go»: Haití. Esta doble continuidad —entre autoridades y pueblo, por una parte, y entre «enemigos de España» y «el enemigo» de República Dominicana- tiene un contenido «social»-en el sentido que atribuye Peña Batlle a esta nación- que se expresa particularmente a través del enfrentamiento armado. Se descontextualiza la situación histórica para resaltar la fiereza de los enfrentamientos. ${ }^{83}$ A continuación la asimilación de aquella lucha armada en los inicios de la colonización francesa como una característica básica de la sociedad-territorio, proporciona una justificación histórica de la matanza perpetrada por el régimen trujillista en 1937. La asociación se asegura constantemente subrayando la continuidad de esa «lucha social» y su carácter «inconcluso».

En realidad recurre a una imagen de lo nacional por fuera y por encima de lo social. En esa visión «los dominicanos» actúan -en una brillante muestra de disciplina - como un solo bloque tras el líder espiritual que encarna el sentimiento de «la hispanidad», representado por su autoridad. A eso queda circunscrita la actuación del pueblo-territorio, que no conoce otra voluntad que ajustar su comportamiento a las opiniones de su autoridad, sea ésta eclesiástica, político-militar o social.

No es por casualidad que sea en este nivel donde se producen todos los acontecimientos de orden interno -odios, intrigas- a veces detalladamente referidos. Queda excluida cualquier observación sobre los grupos sociales explotados, nivelados por su arbitraria categoría de sociedad. La mención de los esclavos es sólo para identificarlos a Haití -y al tremendo enfrentamiento entrc haitianos y dominicanos-, o en el mejor de los casos para descartar la importancia que tuvo esta institución social en la isla Española. No hay ninguna mención de las sublevaciones de esclavos que precedieron y sucedieron a la rebelión de Enriquillo. Mientras que esta rebelión es asociada con la resistencia frente a los ocupantes franceses de una manera realmente artificiosa. ${ }^{84}$ Pero esa exclusión

83 «Era, sin embargo, difícil salir vivo de aquellos encuentros, en los que los hombres se portaban como fieras. (...). La guerra se hacía sistemáticamente a muerte». Ibidem, págs. 227-228.

84 Ibidem, pág. 231. 
arrastra consigo los procesos demográficos, económicos y sociales en general. En esto su concepto se aparta del de Américo Lugo, quien prestó atención a la dinámica demográfica en función de factores políticos y económicos.

Con relación a las configuraciones sociales, todo su empeño está puesto en no reconocer más distinciones que los caracteres definidos por los personajes individuales. Asume una visión psicologista de la historia, con lo que asegura una visión heroica compatible con la exaltación nacionalista que procura sostener. No hay clases sociales por definición. Pero este arbitrario proceder tiene consecuencias. Por una parte, la única fuerza de cohesión posible de esa sociedad-territorio es la amenaza externa: la presencia del enemigo como una entidad cuasi demoníaca, a la que tiene que apelar incesantemente. Esa sobredimensión, apenas deja espacio para la vida propia de la sociedad: «La colectividad dominicana no tuvo reposo ni espacio moral para darse a la tarea de su propia formación. Vivió como le permitieron los otros que viviera: en la agonía de no perderse para siempre. Perdernos era dejar de ser españoles». ${ }^{85}$

La relación entre nación y sociedad, que supone la supeditación de la segunda a la primera, se traduce en el escaso margen para entender el funcionamiento interno de la sociedad-territorio. No hay más que caracteres, funciones y jerarquías. La existencia de tales caracteres daría la medida de los hombres destacados en esa sociedad: su virilidad, arrojo, dotes de autoridad, o por el contrario, su vileza, perversidad, etc. De ello proceden diferentes conflictos que aquejan la sociedad-territorio; frecuentemente se encuentran en lucha los caracteres nobles con los perversos; ${ }^{86}$ son casos paradigmáticos: el arzobispo Dávila Padilla frente al gobernador, capitán general y presidente de la Audiencia, Antonio Osorio, en los años finales del siglo XVI; o el caso de Montemayor de

85 Peña Batlle, El Tratado..., pág. 19.

86 Por ejemplo: «El Presidente Peñalba sólo desarrolló un programa: destruir por todos los medios posibles la obra material de gobierno realizada por su antecesor, y con ella el prestigio de Montemayor de Cuenca», Peña Batlle, Lq isla..., pág. 193. 
Cuenca ${ }^{87}$ frente a un haz representado por el arzobispo, ${ }^{88}$ los oidores y el presidente de la Audiencia, el conde de Peñalba, y don Rodrigo Pimentel. ${ }^{89}$

Resultado de lo anteiior, la sociedad-territorio se disuelve en una concepción psicologista de la historia. ${ }^{90}$ La materialidad de esta dimensión se revela en el héroe y su contrincante, en la fuerza de su confrontación y su enorme impacto en la configuración de la realidad. Pero la razón de ese conflicto que compacta a toda la sociedad tras los individuos que encarnan la nación, está dada en un nivel distinto de lo propiamente material.

2. La dimensión espiritual de lo nocional está formada por la cultura, entendida como «molde» social — «forma social», escribe Peña Batlle-, que por extensión abarca las letras, las artes, las ciencias, así como sus instituciones (la escuela, seminarios, universidades); pero también los actos cotidianos, ya sean comportamientos religiosos, hábitos alimenticios o manera de vestir. La cultura, pues, define patrones de comportamiento, estéticos, morales, etc., inmutables, fijados arbitrariamente. No sólo la cultura no es un proceso dinámico, un quehacer creativo y colectivo, sino que se la desfigura para aparecer como simple mimetismo, reproducción inevitable de lo dado en este caso por el término dominante que es el Imperio. Así entendida, la cultura no es más que lecho de Procusto que constituye la mirada del poder, a la que forzosamente tiene que acomodarse lo dominicano. Pero en su

87 \&La llegada de Montemayor al gobierno en 1653 produjo el mismo efecto del guijarro que cae en las aguas estadizas de un remanso, pues estaban todos acomodados a las facilidades, dejadeces e imbecilidades de los Pérez Franco (el Presiden:e anterior, R. G.), y cada uno vivía en el cotejo de sus intereses particulares, sin preocuparse mayormente de la cosa pública (...). El hombre era duro. recto, honrado y valiente, y todos le tenian miedo». Ibídem, págs. 190-191. El subrayado es nuestro.

88 «De los apurados por irse (...) fue el Arzobispo Francisco Pío de Guadalupe y Téllez, cobarde, insidioso e intrigante. Luego se defendió (...), acumulando odio y veneno sobre Montemayor». Ibídem, pág. 187.

89 «Bribón redomado, al decir de Utrera, contrabandista, usurero, rico, sobornador, por cuyas manos pasaban todos los resortes de la vida colonial, y sin cuya anuencia era difícil el gobierno». Ibídem, pág. 191.

90 Esta concepción psicologista de la historia le permite obviar los procesos sociales que están involucrados en los hechos que refiere. 
determinación más estricta, la noción de cultura en Peña Batlle remite a una forma de control social.

Refiriéndose a las formas religiosas y culturales de la constitución dominicana, señala cómo su contenido social reflejaba la «influencia del Patronato» y la Contrarreforma: la «aplicación estricta y exigente» de las resoluciones del Concilio de Trento y el Patronato indiano fijó el carácter al «gobierno canónico de las Indias»; con su aplicación la corona castellana no sólo modeló las instituciones sino los prejuicios y sentimientos de la colectividad dominicana durante su formación. «De aquellas formas de gobierno tenía que surgir necesariamente un sistema de cultura y una manera de vivir adecuados a las modalidades de la administración». ${ }^{91}$

Esto implicaba encerrar la cultura en una forma definitiva alcanzada en una situación pasada, que Peña Batlle parece identificar con el catolicismo colonial. Los valores que reflejan la visión del poder se resuelven en «forma cultural» sin mediación alguna: se traducen en «prejuicios tradicionales». La sociedad no interviene sino como receptora. Todavía más: la cultura se acata del mismo modo que una ley, cuando no, la cultura se aplica sobre el colectivo social. La sociedad no cuenta para crear la cultura sino para actuar conforme a lo establecido de antemano por leyes y resoluciones desde el poder, lo que confiere un sentido restrictivo y autoritario a esta noción de cultura.

Una vez dado el contenido estático de la cultura, con esta noción cabía oponer en términos ontológicos los pueblos dominicano y haitiano, sin necesidad de apelar, de primera intención, al racismo: «El dominicano no podía vivir ni comportarse como vivía y se comportaba el haitiano. El uno y el otro procedían de formaciones muy distintas. No es necesario detenerse en distingos raciales para seguir adelante en este orden de ideas. El dominicano había construido su sentido de grupo en un mundo de valores y jerarquías sociales de carácter netamente español; el haitiano, por el contrario, representa, como tipo social, la negación de todos

91 Peña Batlle, El Tratado..., págs. 16-17.

Tomo XLVIII 
aquellos valores». ${ }^{92} \mathrm{La}$ alternativa era la perdición: «Perdernos era dejar de ser españoles» - dice- En consecuencia, el racismo aparecía mediatizado dentro de esa noción cultural, aunque esa atenuación va cediendo a medida que avanza en su teorización, hasta llegar incluso a negarle calidad nacional al colectivo haitiano. ${ }^{93}$

Pero, además, esa noción ofrecía la posibilidad de introducir la impugnación de Hostos extendiéndola a todo el pensamiento liberal, incluso más allá de nuestras fronteras. Según su planteo, los movimientos de independencia en América Latina se produjeron a despecho del liberalismo, «cuando les maduró su conciencia» formada en los modelos imperiales; a lo sumo, el liberalismo proporcionó un «molde político» a la independencia. ${ }^{94}$

Al disminuir el papel de la ideología liberal que dio sentido al movimiento Trinitario y a todo el viejo liberalismo nacional - la tradición de pensamiento liberal anterior al de signo hostosiano-, de paso descartaba toda contribución del liberalismo a la conformación nacional. Considera que la independencia dominicana dependió no de un ideal político sino de «un definido sentimiento de cultura». Fue un movimiento instintivo, hallándose los dominicanos «obligados por necesidades apremiantes de preservación cultural, para resguardo y defensa de las formas de nuestra vida social propiamente dicha». Y puntualiza sobre el término cultura: «Téngase presente que la palabra cultura se usa aquí en su más estricta acepción sociológica»; ${ }^{95}$ esto es, los prejuicios del hispanismo y del antihaitianismo de las clases dominantes -exacerbados desde principios de siglo- que en su «sociología» se extienden a todos los grupos sociales dominicanos de todas las épocas.

92 Peña Batlle, M. A.: Prólogo, en: Emiliano Tejera. Antología, Ciudad Trujillo, 1951, pág. 21. Nótese que las ventajas de esa noción de «cultura» propia de los defensores de la «diferencia», ya eran conocidas para nuestro autor.

93 Es el máximo empeño de la obra que dejó inconclusa: «Pensamos (...) que el solo hecho de la necesidad de conquistar por la fuerza la condición básica de hombre, (...) significa en un grupo social la ausencia completa de toda característica de nación». Peña Batlle, M. A.: Origenes del Estado Haitiano (1954), en: Ensayos históricos, Santo Domingo, 1989, pág. 179.

94 Ibidem, págs. ¿4 y 52.

95 Peña Batlle, Émiliano..., pág. 20. 
3. Junto a los caracteres analizados más arriba, la jerarquía es un elemento interno de la unidad analítica sociedad-territorio en el concepto peñabatlleano de lo nacional. Ella remite a la cuestión del orden, noción clave del pensamiento conservador. Peña Batlle se esfuerza en presentar este orden como un sistema religioso de convivencia en el que no existen mayores contradicciones sociales y del cual se exluye todo signo de explotación; no duda en negar el carácter colonial de la dominación española: «El sistema de la colonización propiamente dicha o de la explotación no es engendro español, (...) España creó su Imperio a través de un sentimiento religioso. (...) España no fomentó colonias ni fundó Compañías privilegiadas de colonización. Confundió sus esencias con las de las regiones adonde llegaba para hacer de ellas provincias y entidades, que luego se convirtieron en naciones a su semejanza. España civilizó medio mundo sin explotarlo. No tuvo el genio comercial de los pueblos protestantes, pero sí incomparable sentido de convivencia». ${ }^{96}$

Este orden, al igual que los individuos descollantes de la sociedad-territorio que actúan guiados por un sentimiento cultural, tiene conexión con la dimensión espiritual. Las manifestaciones concretas del orden pueden verse en derecho privado y público, así como en el derecho entre las naciones, el derecho internacional; ${ }^{n}$ pero la fuente de este derecho, remite al punto cardinal: el estado. Para el caso de la noción histórica que nos ocupa, Peña Batlle ubica señaladamente esa fuente en el estado imperial católico de Carlos V y Felipe II.

Detengámonos un momento en el problema del estado. El planteamiento de la cuestión en el pensamiento social dominicano se debe en primer lugar a Hostos y a Américo Lugo. Ellos entendieron, como momento decisivo de la formación de un estado democrático, la asunción efectiva por los ciudadanos de las nociones del deber y el derecho sociales inscritas en una moral racionalista.

96 Peña Batlle, La isla..., págs. 220-221.

97 La importancia que le concede en el plano histórico también la prestó en sus funciones como canciller, hasta el punto que se denominó como diplomacia extravertida».

Tomo XLVIII

40.-Anuario 
Este concepto otorgaba primacía a la iniciativa de los individuos como expresión del desarrollo de la sociedad, antes que a las instituciones puramente estatales. Sin que entremos a analizar esos conceptos, cabe anotar que la relación entre sociedad, nación y Estado, ya había sido establecida en una solución democrática por Hostos desde finales del siglo XIX. La solución autoritaria que da Peña Batlle a esta relación es lo que veremos de inmediato.

Para ser legítimos, el orden y la jerarquía que supone deben tener sus fuentes en la tradición. Todo orden ha de estar justificado en la historia. Si bien los elementos de su concepto nacional son la sociedad-territorio y la cultura, la nación supone la articulación de esas dos dimensiones. Pues bien, esa correspondencia viene dada 'constitutivamente', esto es, de manera originaria, aunque está sometida a contingencias temporales, históricas. A ella se refiere la noción fundamentalísima de tradición.

La tradición como categoría abstracta en Peña Batlle, pero también en el pensamiento conservador, equivale a esa correspondencia a la que se atribuye carácter originario y esencial. Esos dos atributos no son casuales: rota la unidad inicial, entonces la tradición estaría en el fondo de cualquier actuación consecuente de la sociedad o los individuos sobresalientes que la encarnan para restituirla. Como expresa en un arranque de inspiración:

«Eso sí ha sido duro y consistente. A ese hueso sí que no pudieron hincarle el diente ni ingleses, ni franceses, ni holandeses, ni herejes, ni negros, ni bucaneros, ni filibusteros, ni malandrines, ni ladrones. Eso ha persistido y persistirá, porque se nutrió de la más pura leche imperial, de la que amamantó a Carlos $\mathrm{V}$ y a Felipe II. Eso persiste porque es brote de la perenne semilla hispánica que aquí sembraron los dominicos, los Casas, los franciscanos, los Ovando, los Ramírez de Fuenleal, los Alonso Suazo, los Fuenmayor, Los Montemayor de Cuenca, los Solano y Bote, los Joaquín García. Eso persiste porque lo inmortal no muere, porque Cervantes, Santa Teresa y Fray Luis pudieron escribir en Santo Domingo, a la sombra de nuestras piedras ilustres, sus obras eternas. 
Eso persiste porque aprendimos a hablar en español y a sentir en católico, porque nos amparó la Contrarreforma y somos los causahabientes lejanos, pero los mejor probados en América, de aquella magna e invencible concepción religiosa y política que salvó para siempre a lo hispánico del naufragio y el hundimiento». ${ }^{98}$

Pues bien, rota la unidad originaria (por las contingencias históricas), una vez hallada (gracias a la heroicidad de algunos individuos sobresalientes guiados por su sentimiento de cultura) toca al estado asegurar la correspondencia entre sociedad-territorio, en cuanto dimensión material, y la cultura, en cuanto dimensión espiritual. Vale decir, el estado perpetúa la tradición que otorga consistencia a la nación. Aplicar esta noción a las situaciones históricas, implica matizar el enunciado anterior: El estado debe asegurar en su duración, es su obligación, su función, la tradición que mantiene cohesionadas las dimensiones material y espiritual de la nación. Perpetuar la tradición es mantener la esencial de la nación, lo que dejaría espacio para elevar su bienestar material y espiritual; como instrumento, el estado es voluntad y fuerza ejecutoria para reponer en su cauce nacional a la sociedad.

Conforme a este concepto, tras cobrar «carácter social la mutilación de Osorio», la acción del Estado imperial en el siglo XVII, dio consistencia a la frontera: «(...) una evidencia ya concluida en 1680 (...) es la de que en esa fecha la ocupación francesa encontró un límite, que no sobrepasó jamás». Los bucanerosfilibusteros habrían conseguido en la segunda mitad del siglo XVII «destruir las vías de comunicación del Imperio español y aniquilar su comercio. El Tratado de Utrecht de 1713 es hijo de los bucaneros-filibusteros con todas sus implicaciones y consecuencias, pero este conglomerado tan activo y tan duro no pudo destruir ni el espíritu ni el país de los dominicanos. Lo español-dominicano, prendido en la parte oriental de Santo Domingo, resistió y supervivió por obra de su propia consistencia». ${ }^{99}$ En 1795, con la cesión

98 Peña Batlle, La isla.., pág. 222.

99 Ibídem, págs. 234-235. 
a Francia de la parte oriental de la isla, se inicia el período de la desnacionalización. La influencia de la Revolución Francesa y de la Revolución Haitiana son los dos agentes inmediatos. El Tratado de Basilea envuelve la «tragedia de Santo Domingo», y es en sí mismo un hecho antinacional por su inconsecuencia con la tradición. «Si se tiene en cuenta - escribe Peña Batlle- el contenido catastrófico de los reinados de Carlos IV y Fernando VII y todo el daño que le causaron a España, nada de sorprendente se encontrará en la tragedia de Santo Domingo». ${ }^{100}$

Se produjo desde entonces la disociación entre los factores que componen la nación y, por tanto, la tradición quedaba sepultada. Detrás de toda acción sensata, por ejemplo, la independencia nacional, no podía haber otra cosa que una vuelta a la tradición para así sacar a flote la nacionalidad. Después de Juan Sánchez Ramírez, le cabe el mérito a Pedro Santana: «Si se coloca el fondo de la independencia dominicana en su justo sentido social de reconquista contra la influencia de Haití y de regreso a la valoración hispánica de nuestra nacionalidad, necesariamente se llegará a la conclusión de que el caudillo no sólo no traicionó a su país sino que trató de consolidar sus cimientos sociales con la anexión a España». ${ }^{101}$

La influencia racionalista y positivista en los dirigentes dominicanos contribuía a debilitar las fuerzas espirituales de la tradición. Lo peor fue la influencia hostosiana que planteó la educación racionalista y la descentralización como vías para realizar el ideal nacional. Pero si fracasaron en ese empeño se debió, a los ojos de Peña Batlle, a que no era la sociedad la que podía regresar por sí sola a sus cauces originarios hispánico y católico, puesto que ella se hundía en «el caos de la anarquía» y todo el país en «el desorden y la incapacidad de gobierno». Esa tarea no podía realizarse sin el concurso de una voluntad suprema que encarnara la tradición, concentrando en sí misma toda la fuerza necesaria para res-

100 Peña Batlle, El Tratado.... pág. 12.

101 Peña Batlle, Emiliano..., pág. 26. 
catar las esencial de la nacionalidad. Por supuesto, Peĩa Batlic ha identificado esa voluntad en Trujillo. ${ }^{102}$

Según esto, desde el Tratado de Basilea, pues, había desaparecido el Estado que se apoyaba en la tradición. Con ello se había puesto en peligro la existencia de la nación. Si bien la independencia de 1844 respondía a un imperativo dictado por la «cultura», todavía faltaba la presencia fundamental del estado que mantuviera cohesionada esa cultura con la sociedad-territorio. Por falta de un estado el problema nacional —que consistía en el descoyuntamiento de sus dos dimensiones - no tenía solución. Esto fue lo que aportó el despotismo trujillista:

«La nación se encuentra a sí misma, después de un largo proceso de desarrollo material y espiritual, en las formas finales de su organización política. que son las del Estado. La nación es historia y tradición, el Estado es derecho y objetividad legal. (...) La convivencia de un grupo nacional descansa sobre la eficacia de la ley, y ésta no podría resultar útil sino cuando descanse, a su vez, sobre el principio de autoridad bien entendida. La causa eficiente del Estado, es pues, la autoridad acatada y respetada. Del respeto a la autoridad dependen el orden y la disciplina sociales, factores ínsitos en el progreso de un país. Nuestros pensadores políticos echaron de menos siempre en la vida pública dominicana la cohesión de sentimientos que hace viable una máquina administrativa nacional. Eso equivalía, precisamente, a la ausencia del Estado, porque éste no se concibe sino como medio de expresión de un ideal nacional definido y concreto». ${ }^{103}$

102 «La única Revolución posible en Santo Domingo la hemos visto realizarse ya. Ha sido el resultado de una genuina comprensión de nuestras esencias sociales (...). Eso no se ha obtenido con los maestros de escuela, ni por vías de descentraljzación ficticia y teórica. El resultado social y político en que nos encontramos es, por el contrario, obra de una sola voluntad creadora, de una suprema concentración de energias, de una imprescindible concentración de tiempo y de una fe ciega en los destinos de la Nación: todo eso es Trujillo». Peña Batlle, Semblanza..., pág. XXV.

103 Peña Batlle, Politica..., págs. 194-195.

Tomo XLVIII 
Ese estado había sido creado nuevamente. Pero no desde la sociedad, inmersa en el caos y la pobreza, como habían pensado los hostosianos. Sucede al estado lo mismo que a la cultura que resultaba de una voluntad exterior, impuesta por la providencia. Así se cerraba el circuito de toda la construcción peñabatlleana de lo nacional: colocando a Trujillo como el «creador» del estado y resolviendo definitivamente «la tragedia» nacional. Se consagraba así el estado despótico como la forma adecuada para conseguir el progreso y el bienestar.

Peña Batlle colocó al estado en el centro de su concepto nacional, que concibe como instrumento. Desde el estado se organizaría la sociedad mediante la fuerza y el consenso, implantando instituciones a las que se obligaría a adaptarse a la sociedad. Exactamente era la relación contraria a la propuesta por Hostos, quien partía de la formación de los hombres y no de su domesticación, para alcanzar la constitución de un estado democrático, distinto al existente entonces en el país de carácter oligárquico. El estado despótico orquestado por la dictadura, aseguró el dominio de un bloque de poder estatal y la sujeción del estado al sistema imperialista.

Aparte de las premisas subjetivistas en que se apoya ese concepto, el planteamiento no parece ofrecer mayores dificultades. Visto en general, su esquema lógico es sencillo y cerrado. Pero su montaje en términos históricos resulta, como consecuencia de las premisas que lo sustentan, necesariamente artificioso y fraudulento. $\mathrm{Ni}$ la sociedad ni la cultura ni el estado podrían reducirse a los términos planteados por Peña Batlle, puesto que sus premisas rechazan cualquier confrontación empírica. Su valor y significado reside en haber superpuesto esta solución teórica conservadora, «libre» de impurezas liberales al debate procedente de la herencia ideológica hostosiana. Ciertamente, tenía en favor suyo el hecho de que el debate había sido cerrado ya mediante la integración de un contingente importante de los intelectuales liberales al régimen. Pese a todo, su propuesta de ajuste ideológico entre proyecto nacional y dominio despótico, por varias razones, no fue universalmente seguida por el conjunto de los intelectuales tru- 
jillistas, y hasta el final de la dictadura las concepciones liberales hostosianas se entremezclan con los postulados ad boc de la dictadura, dentro de los cuales se encuentran, desde luego, las formulaciones peñabatlleanas.

En este sentido las elaboraciones históricas de Peña Batlle no representan la continuidad del debate liberal sino su cierre autoritario. Abandonada la preocupación por la cuestión nacional con sentido democrático, vemos a un Peña Batlle que falsifica a Hostos, imputa y silencia a Lugo, obvia e hipertrofia informaciones históricas que tiene a la mano, con gesto autoritario en la impunidad que garantizaba el estado despótico. A la justificación histórica y política de ese dominio apostó todas las fuerzas de su genio. Aun dentro de la misma racionalidad burguesa esa reflexión resulta un sofisma viciado por sus prejuicios. La conceptualización histórica de la nación dominicana elaborada en los estudios de Peña Batlle, deliberadamente no ofrece otra salida que el despotismo.

Mueve a la reflexión, empero, que bajo el mando intelectual con que lo cubrió Peña Batlle, el prejuicio antihaitiano siga siendo exaltado en la República Dominicana a la categoría de «esencia nacional», actuación que no puede ocultar sus propósitos políticos reaccionarios; cierto que esto es posible porque queda más de un prejuicio de herencia despótica en la mentalidad dominicana. De esa manera seguirá siendo su concepto histórico de la nación dominicana un recurso del pensamiento antidemocrático.

Pero por esa misma razón el debate sobre el proyecto y la construcción nacional sigue abierto y no donde pretendidamente lo situara Peña Batlle.

Raymundo GonzÁlez 